DA VID LIPTON

Woodrow Wilson Center

JEFFREY D. SACHS

Harvard University

\title{
Prospects for Russia's Economic Reforms
}

AT THE START of 1992, less than six months after the fall of communism and less than one month after the dissolution of the Soviet Union, Russia embarked with remarkable dispatch on a program of radical economic reforms. ${ }^{1}$ The economic reforms themselves, under the direction of Acting Prime Minister Yegor Gaidar, combined with the collapse of the Soviet state, have created an enormous opening for decentralized, marketbased economic activity. Within a short period of eight months, almost all centralized operations of the command economy ceased; meanwhile, new commercial structures are developing rapidly. Spontaneous market activity is evident not only in the "kiosk boom" of Moscow, but also in growing market-based trade within Russia and between Russia and the rest of the world.

The benefits of sustained economic reforms are likely to be very great-much greater than is commonly supposed. The old command system was so inefficient and destructive of the quality of economic life

The authors are economic advisors to the government of Russia. The views expressed in this paper are strictly our own and do not necessarily reflect the opinions of the government of Russia. Some of the information presented here is based on unpublished data obtained from the government of Russia. We would like to thank Anders Aslund, Marek Dabrowski, Stanley Fischer, and Charles Wyplosz for very helpful discussions of many of the topics covered in the paper. Our work has been supported by a project on economic reform at the World Institute for Development Economics Research and by the government of Sweden.

1. For an early discussion of Russia's economic reform program, see Fischer (1992). 
that enormous scope exists for increases in average living standards within a few years, particularly as resources are shifted out of the military-industrial complex into other sectors.

Nonetheless, Russia's financial conditions remain horrendous because of the profound disarray left behind by the communist regime. Hyperinflation is a real risk-indeed, the main risk now to democratization and successful transition to a market economy.

Although the tasks of stabilization and transformation are daunting, we believe that there is a way forward with a reasonable prospect of success, based on tight monetary and fiscal policies to prevent hyperinflation. (We caution, however, that this way is under heavy attack from industrialists seeking large credits to keep alive loss-making state enterprises.) The tight financial policies would be accompanied by rapid privatization of enterprises and swift opening of international trade to enforce domestic competition, spur exports, and end the shortages of key commodities on the home market. Similar prescriptions are demonstrating their efficacy in much of Eastern Europe. In Poland, for example, which also began its reforms with hyperinflationary conditions, the transition to a normal, market-based economy is on track. After two and one-half years of reform, inflation is under control, shortages have ended, exports are booming, output is rising, and the private sector now accounts for more than half of total employment.

In Russia, reforms are clouded in confusion. Data are incomplete and misleading, and easily misinterpreted to give an overly bleak account. Many criticisms within Russia, which are repeated at face value in the West, are politically motivated rather than analytically sound. The many adverse trends in the Russian economy are attributed to the reforms themselves, rather than to the legacy of the old regime. This mistaken attribution results in an overstatement of the "costs" of the reforms, and therefore an undue pessimism about the reform policies themselves. This has resulted in strong pressures to abandon the reforms, even before they have begun to take hold. The timetable for judging the reforms is also frequently out of kilter, sometimes wildly so. For instance, the speaker of the Russian parliament, Ruslan Khasbulatov, called for the demission of the government ten days after the start of reforms. ${ }^{2}$ Former President Gorbachev demurred, saying that the govern-

2. See "Russian Parliamentary Speaker Attacks Yeltsin Government,"Reuter Library Report, January 13, 1992, dateline Moscow. "The president should distance himself from 
ment deserved ten more days! $!^{3}$ While we believe that the government and the West have been far too slow to face up to certain urgent tasks, thereby adding to the risks of hyperinflation, we must also stress that the reform process is a mere eight months old.

The real question for Russia, in our opinion, is not primarily one of economic strategy, but rather one of political management of economic reform in the next few years. Will Russia's political and administrative institutions prove sufficient to head off damaging hyperinflation? Will rear-guard actions by old power structures in the military-industrial complex succeed in derailing key reforms? Will the nascent democratic institutions survive the challenge of social turmoil in the face of dramatic economic change? We believe that the answers to all of these questions can be favorable, but success will require intensive effort and skilled political management.

We discuss these issues as follows. First, we outline the basic economic situation inherited by the Yeltsin-Gaidar government and the strategy of economic reform that was chosen. We emphasize the twin nature of the task: urgent monetary stabilization and long-term creation of a market economy. The monetary task has been particularly complex, given the breakdown of the old Soviet monetary and financial system and the bizarre and destabilizing nature of the monetary arrangements that emerged at the start of 1992. Monetary policy has not been conducted with sound judgment or with vigor; financial disarray remains, and the flood of credits since July 1992 leaves Russia facing the risk of imminent hyperinflation.

Second, we discuss the social and political context of the reforms to try to judge whether they will be sustainable. Of course, the overall process is at a very early stage and the data are sketchy and inaccurate. Therefore, we draw on lessons not only from Russia itself, but from reforms in other countries, including recent experience in Eastern Eu-

the government, which is not only a failure but simply incompetent," Interfax quoted Khasbulatov as saying after meeting a delegation of Italian parliamentarians. "Such a situation is developing that we [parliament] can either suggest to the President he remove the incapable government, or do it ourselves."

3. See Christopher Boian, "Gorbachev, Back in Public Arena, Says Further Economic Reforms Needed," Agence France Presse, January 14, 1992, dateline Moscow. "Gorbachev said the government should be given another 10 days before deciding whether to quit." 
rope. In our view, the social basis for the reforms exists. The real test will be in the area of political reform and in the extent of Western support.

\section{The Economic Inheritance}

The general outlines of the Stalinist economic legacy are now rather well known. We describe first the main structural dimensions, and then the macroeconomic inheritance. The key structural characteristics are: a concentration of resources in heavy industry, particularly in the military-industrial complex, to the neglect of consumer industry and services; state or collective ownership of almost all productive assets; bureaucratic control over prices, domestic resource flows, and international trade; and the absence of a legal framework to protect private property and to support market activity. Some data and a few comments are in order on the first two points.

\section{The Structural Legacy}

Table 1 shows the allocation of output and labor across major sectors of the economies of the former Soviet Union (FSU) and the United States. We see clearly the remarkable concentration of resources in industry and the neglect of the service sector in the FSU. Within Russian industry, resources are heavily concentrated in machine building, which includes much of the armaments sector and other parts of the military-industrial complex (MIC). The MIC was built up by an extensive system of implicit and explicit subsidies, which pushed resources into the sector at the expense of other parts of the economy. In particular, the MIC was guaranteed cheap access to energy and other raw materials, access to rationed foreign exchange, and heavy budgetary resources for investment projects.

The exact size of the MIC under the old regime was not precisely known, although one recent estimate puts it at around 20 percent of industrial employment, 16 percent of industrial production, and 12 percent of industrial capital of the USSR. In all, MIC employment is estimated at 7.5 million personnel, or about 5 percent of the Soviet work force. ${ }^{4}$ 
Table 1. The Structure of Output and Employment in the United States and the Soviet Union

Percent of total

\begin{tabular}{|c|c|c|c|c|}
\hline \multirow[b]{2}{*}{ Sector } & \multicolumn{2}{|c|}{ Output ${ }^{\mathrm{a}}$} & \multicolumn{2}{|c|}{ Employment } \\
\hline & $\begin{array}{l}\text { United } \\
\text { States }\end{array}$ & $\begin{array}{l}\text { Soviet } \\
\text { Union }\end{array}$ & $\begin{array}{l}\text { United } \\
\text { States }\end{array}$ & $\begin{array}{l}\text { Soviet } \\
\text { Union }\end{array}$ \\
\hline Industry & 23.5 & 48.9 & 17.6 & 28.9 \\
\hline Electricity & 3.3 & 2.2 & 0.8 & 0.6 \\
\hline Fuel & 2.3 & 5.0 & 0.7 & 1.2 \\
\hline Metallurgy & 1.1 & 3.7 & 2.1 & 1.5 \\
\hline Chemical & 2.2 & 3.1 & 1.7 & 1.4 \\
\hline Machine bldg. and metal working & 8.7 & 15.1 & 6.3 & 13.0 \\
\hline Wood and paper & 1.7 & 2.1 & 1.7 & 2.1 \\
\hline Construction materials & 0.6 & 2.1 & 0.5 & 1.9 \\
\hline Light industry & 1.0 & 6.1 & 1.8 & 3.7 \\
\hline Food & 2.4 & 8.1 & 1.5 & 2.4 \\
\hline Other industry & 0.3 & 1.4 & 0.3 & 1.3 \\
\hline Construction & 6.1 & 10.7 & 4.6 & 11.5 \\
\hline Agriculture & 1.9 & 9.3 & 2.7 & 19.3 \\
\hline Transportation and communication ${ }^{b}$ & 5.8 & 10.1 & 4.0 & 7.2 \\
\hline Trade and distribution & 11.2 & 6.1 & 22.2 & 8.0 \\
\hline Other & 1.5 & 0.8 & 1.4 & 0.6 \\
\hline Services & 50.0 & 13.9 & 47.6 & 24.5 \\
\hline
\end{tabular}

Source: Kwon (1992a, p. 56). Data for the United States are for 1986. Data for the Soviet Union are for 1988.

a. Output is measured as value added in domestic currency.

b. Includes passenger services as well as goods services.

These estimates must be judged with care. They count the output and employment of enterprises under the direct control of the USSR Military-Industrial Commission, known by its Russian acronym as VPK. The VPK supervised the work of eight ministries. ${ }^{5}$ The enterprises under VPK supervision in fact produced for both military and civilian purposes. ${ }^{6}$ At the same time, enterprises outside of direct control of the

5. The ministries were: the Ministry of Atomic Power and Industry (responsible for the development and production of atomic weapons); the Ministry of General Machinebuilding (responsible for the development of space technology and ballistic missiles); the Ministry of Defense Industry (responsible for missile technology and conventional forces equipment); the Ministry of Aviation Industry; the Ministry of Shipbuilding; the Ministry of Radio Industry (responsible for mainframe computers and radar); the Ministry of Electronics Industry (responsible for electronic components); and the Ministry of Communications (responsible for communications equipment and telephone and postal services). For details, see Cooper (1991, pp. 6-11).

6. One estimate, mentioned by Cooper $(1991$, p. 14), holds that 20 percent of the enterprises under the VPK produce solely for civilian purposes. 
Table 2. Indicators of Raw Materials Production and Energy Consumption, 1988

\begin{tabular}{|c|c|c|c|c|}
\hline Commodity & $\begin{array}{l}\text { Soviet } \\
\text { Union }\end{array}$ & $\begin{array}{l}\text { United } \\
\text { States }\end{array}$ & $\begin{array}{l}\text { West } \\
\text { Germany }\end{array}$ & Japan \\
\hline & \multicolumn{4}{|c|}{ Millions of metric tons, except energy $y^{a}$} \\
\hline Crude steel & 163.00 & 90.60 & 41.00 & 105.70 \\
\hline Refined copper & 1.00 & 1.86 & 0.43 & 0.96 \\
\hline Primary aluminum & 2.50 & 3.94 & 0.74 & 0.04 \\
\hline Synthetic rubber & 2.44 & 2.34 & 0.49 & 1.30 \\
\hline \multirow[t]{2}{*}{ Primary energy } & 27.28 & 38.93 & 5.53 & 8.07 \\
\hline & \multicolumn{4}{|c|}{$\begin{array}{l}\text { Thousands of metric tons per U.S. billion dollars of } \\
\text { GDP, except energy }{ }^{\mathrm{b}}\end{array}$} \\
\hline Crude steel & 280.00 & 18.49 & 34.35 & 36.47 \\
\hline Refined copper & 1.71 & 0.38 & 0.36 & 0.33 \\
\hline Primary aluminum & 4.28 & 0.80 & 0.62 & 0.01 \\
\hline Synthetic rubber & 4.18 & 0.48 & 0.41 & 0.45 \\
\hline Primary energy & 46.78 & 7.94 & 4.63 & 2.78 \\
\hline
\end{tabular}

Source: CIA (1990), International Financial Statistics (IMF, September 1992), and the Economist (1990).

a. Commodities are measured as millions of metric tons of production. Primary energy is measured as millions of barrels per day, oil equivalent, of consumption.

b. Commodities are measured as thousands of metric tons of production per U.S. billion dollars of GNP. Primary energy is measured as thousands of barrels per day, oil equivalent, of consumption per U.S. billion dollars of GDP. GDP figures are in 1988 current dollars. U.S. billion dollars of GDP figure for the Soviet Union is from the Economist (1990).

MIC complex provide inputs into military production, but are not counted in the MIC. ${ }^{7}$ The estimate is also made somewhat arbitrary by the huge price distortions, secrecy, and the virtual lack of public information concerning the employment and production in the nuclear weapons sector.

Naturally, the MIC fares rather badly overall in the face of market reforms. As soon as the sector is opened to market pressures, it is squeezed between falling demand, resulting from sharp budgetary cutbacks on armaments spending, and a supply squeeze, resulting from a loss of privileged access to scarce resources. Of course, the reduction of military production in favor of civilian production is a key goal of the economic reform, but also the source of intense political attack on the government. As we shall recount later, the pressures from the MIC to slow or reverse the economic reforms have been a central feature of Soviet, and then Russian, political life since 1987.

An illustration of the structural maladjustment caused by the relentless pursuit of heavy industry is seen vividly in table 2 , which compares industrial production in the Soviet Union and several industrial econo-

7. These include enterprises of the civilian machinebuilding complex (such as trucks and diesel engines) and enterprises of the Ministry of Metallurgy. 
Table 3. Indicators of Retail Trade Services in Various Countries, 1985 Per 10,000 of population

\begin{tabular}{lcc}
\hline \multicolumn{1}{c}{ Country } & Stores & $\begin{array}{c}\text { Employment } \\
\text { in retail trade }\end{array}$ \\
\hline Soviet Union & 20 & 177 \\
United States & 61 & 491 \\
United Kingdom & 61 & 412 \\
Germany & 66 & 383 \\
France & 86 & 335 \\
Japan & 135 & 527 \\
Italy & 175 & 350 \\
\hline
\end{tabular}

Source: Joint Study (1991, vol. 3, table V.2.7, p. 53).

mies in 1988. Despite the fact that the other countries each have an aggregate GNP much higher than that of the FSU, it was the largest steel producer in the world, with a steel output per dollar of GDP fifteen times higher than that of the United States in 1988! The flip side has been the squeeze of the service sector, which can be seen by the paucity of retail establishments in the FSU. Table 3 compares the retail trade sector in the Soviet Union and several major industrialized nations, as of 1985. The number of shops per 10,000 population in the Soviet Union was onethird of the level in the United States and less than one-sixth of the level in Japan.

The second main structural feature we want to emphasize is the overwhelming extent of state ownership. Until the mid-1980s, more than 95 percent of production was in state hands; this has since dropped to around 85 percent with the spread of other forms of ownership, notably private ownership, cooperatives, and joint ventures. Nonetheless, the Russian state remains the nominal owner of about 23,000 industrial enterprises, and perhaps as many as 221,000 enterprises in total. ${ }^{8}$ As we have described earlier for the case of Poland, the vast state holdings require a systemic conception of privatization that moves beyond the sale of enterprises on a one-by-one basis that constitutes the privatization process in most parts of the world. ${ }^{9}$ The government has wisely adopted a strategy for mass privatization that will cover around three-fourths of the industrial capital stock in $1993 .^{10}$

8. Kwon (1992b, pp. 2, 13).

9. Lipton and Sachs (1990b).

10. For an overview of the Russian government's privatization program, see State Committee on the Management of State Property (1992), Djelic (1992), and Kwon (1992b). 


\section{The Macroeconomic Legacy}

The communist regime left behind financial chaos of a sort even more virulent than seen in Poland, Bulgaria, and Yugoslavia, where hyperinflation also erupted in the final stages of the communist collapse. The Russian government inherited a disastrous legacy including: a 1991 budget deficit estimated to be 20 percent of GNP, financed almost exclusively by money issue ; ${ }^{11}$ a monetary overhang, in which $\mathrm{M} 2$ as a percent of GNP had risen to around 65 percent; more than $\$ 65$ billion in external debt, accumulated in a few years, and a complete depletion of foreign exchange reserves; $;{ }^{12}$ a labor force in which nominal wage payments had outstripped official price increases by a very wide margin in the preceding three years; and a currency shared among fifteen new states, each with a new (and inexperienced) central bank issuing the shared currency without coordination with any of the other states. Table 4 summarizes some basic macroeconomic indicators for Russia.

We turn first to wages. In the Soviet Union, just as in the case of Poland and its communist reformers, the Gorbachev-inspired enterprise reforms in 1987 gave increased autonomy to the state-owned enterprises. Understandably, using their new-found flexibility, managers and workers granted themselves large wage increases, at the expense of tax payments to the state budget. The wage pressures were aided and abetted by the "soft-budget constraint" correctly stressed by Janos Kornai. ${ }^{13}$ Even beyond cutting back on transfers to the budget, enterprises could depend on generous subsidies and cheap credits to cover higher wage costs.

The contrast in wage developments in Russia and Poland is highlighted in figure 1. Soviet average industrial real wages increased 79 percent between 1985 and December 1991; by contrast, Polish average real wages for six key sectors increased by 53 percent between 1985 and December 1989. Because the supply of consumer goods grew little, if at all, and certainly not commensurately with the increase in ruble wages, excess demand developed. In a market system, price increases would have

11. $\operatorname{IMF}$ (1992a, table 18, p. 70).

12. Government of Russia.

13. See Kornai (1992) and many of Kornai's earlier works. 
Table 4. Russia's Macroeconomic Performance

\begin{tabular}{lrrc}
\hline \multicolumn{1}{c}{ Indicator and units } & 1990 & 1991 & $1992^{\mathrm{a}}$ \\
\hline Percent per year & & & \\
Real GDP & 0.4 & -9.0 & $\ldots$ \\
Real industrial output & -0.1 & -8.0 & -13.5 \\
Consumer price index & 6.8 & 96.3 & $\ldots$ \\
(Within period) & $\ldots$ & 160.6 & 900.0 \\
Average real wage & 8.5 & -9.5 & $-33.0^{\mathrm{b}}$ \\
Industrial real wage & 6.9 & -5.6 & $-28.0^{\mathrm{b}}$ \\
Ruble M2 (end of period) & & & \\
$\quad$ Nominal & 15.3 & 111.1 & $198.0^{\mathrm{c}}$ \\
$\quad$ Real & $\ldots$ & -19.0 & $-73.0^{\mathrm{c}}$ \\
Percent of GDP & & & \\
Ruble M2 (end of period) & 67.7 & 59.8 & $14.8^{\mathrm{c}}$ \\
Budget deficit & $\ldots$ & 19.9 & 4.4 \\
$\quad$ Portion financed & & & \\
$\quad$ domestically & $\ldots$ & 19.9 & 2.0 \\
Billions of $U . S$. dollars & & & \\
Trade balance & -2.0 & 6.5 & -1.3 \\
Exports & 80.9 & 51.6 & 14.9 \\
$\quad$ Oil & 27.1 & 11.8 & 3.8 \\
$\quad$ Natural gas & 9.6 & 10.3 & 3.4 \\
$\quad$ Other & 44.2 & 29.5 & 7.8 \\
Imports & 82.9 & 45.1 & 16.2 \\
Debt service due & 14.0 & 10.4 & $9.2^{\mathrm{e}}$ \\
$\quad$ Principal & 11.1 & 7.8 & $5.6^{\mathrm{e}}$ \\
$\quad$ Interest & 2.9 & 2.6 & $3.6^{\mathrm{e}}$ \\
\hline
\end{tabular}

Source: Government of Russia, and IMF (1992a, table 18, p. 70, and table 24, p. 77)

a. Based on first six months of 1992 , except where noted.

b. Data for August 1992 in comparison with the average of 1991

c. Data for end of July 1992.

d. Percent of GDP based on annualized estimates of monthly GDP for the final month in each time period. Percent changes for 1992 represent July 1992 in comparison with December 1991.

e. Projected for all of 1992.

dissipated the wage increases. In a system of generalized price controls, the result was intensifying shortages and lengthening queues in the official markets and inflation in the black markets. The statistical real wage was thereby disconnected from actual living standards. If anything, an inverse relationship occurred: higher real wages resulted in longer queues, and thereby a loss of work and leisure time. ${ }^{14}$

14. In our 1990 paper (Lipton and Sachs, 1990a), we pointed out the theoretical possibility of such an inverse relationship. See also Roberts (1992). 
Figure 1. Real Wage Developments in Russia and Poland, 1985-92

Wage index, $1985=1.0$

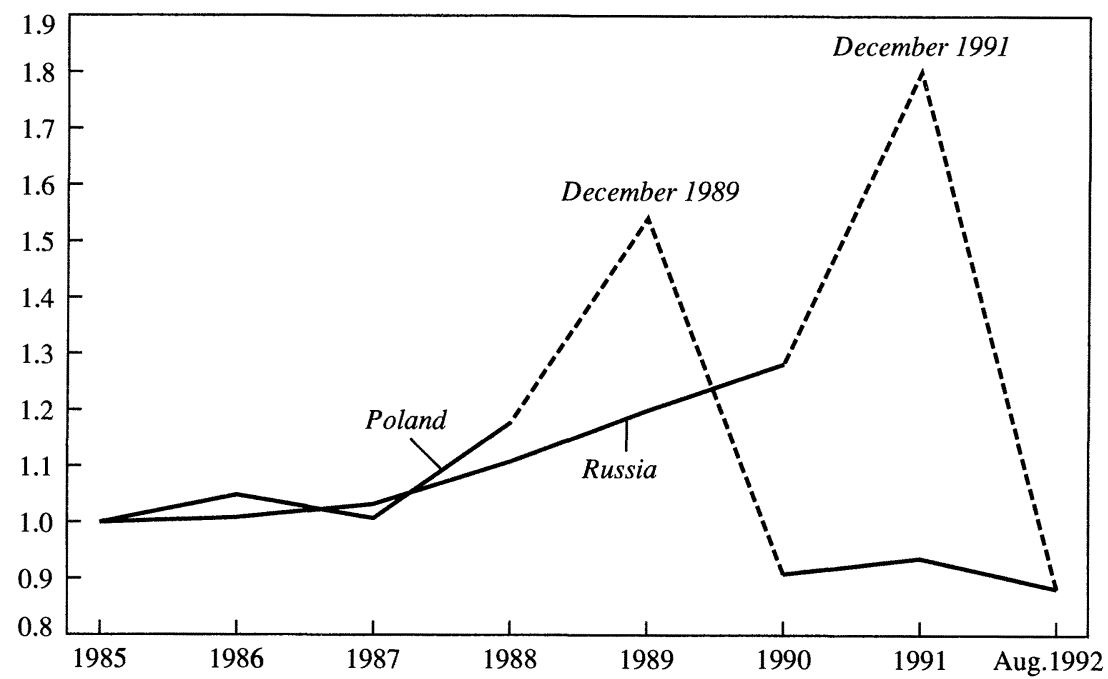

Sources: Government of Russia and Biuletyn Statystyczny (Monthly Statistical Bulletin), various issues. For Russia, the industrial real wage is shown. For Poland, the real wage for the six key sectors of the economy is shown. Wage data are annual averages, except for the year before the economic reform programs were introduced. For that year, the December real wage is shown by the dashed line to capture the peak. For Russia, the peak real wage was in December 1991. For Poland, the peak real wage was in December 1989. The last data point is the real wage for August 1992.

The wage increases preceding radical economic reforms left the Polish and Russian reformers with the politically painful task of freeing prices to end the shortages and to return the real wage to historical levels justified by productivity. Needless to say, in each country, critics accused the reforms of causing a sharp decline in living standards. In Poland, it became an article of faith that the price liberalization had driven down "real living standards" by 30 percent at the start of 1990. In Russia, it is typically asserted that the fall has been around 50 percent. But as we can see from figure 1, and as we shall stress again later, the charge is misleading. Price liberalization basically restored wage-price relations that had prevailed before the 1987 communist-led changes in enterprise autonomy, without representing an actual fall in living standards. ${ }^{15}$

15. We expressed worries about the likely political fallout of Russian price liberalization in a January 1991 article in The Financial Times: "The Polish wage explosion during 1988-89 is being replayed in the Soviet Union . . . The result is that as in Poland until 1989, the measured real wage has skyrocketed since perestroika began, in fact rising by no less 
Table 5. Russia's Balance of Payments, 1990-92a

Billions of U.S. dollars

\begin{tabular}{lrrr}
\hline & 1990 & 1991 & $1992^{\mathrm{b}}$ \\
\hline Current account & -4.5 & 4.1 & -7.7 \\
Trade balance & -2.0 & 6.5 & -2.7 \\
Exports & 80.9 & 51.6 & 34.4 \\
Oil & 27.1 & 11.8 & 9.9 \\
Natural gas & 9.6 & 10.3 & 7.4 \\
Other & 44.2 & 29.5 & 17.1 \\
Imports & -82.9 & -45.1 & -37.1 \\
Service account & -4.1 & -4.6 & -5.9 \\
Interest due & -2.9 & -2.7 & -3.7 \\
Gold sales & 1.6 & 2.2 & 0.9 \\
Capital account & 1.4 & 2.7 & 3.3 \\
Grants & 0.0 & 1.6 & 2.7 \\
Long-term capital (net) & 2.0 & 3.8 & 5.6 \\
Other & -0.6 & -2.7 & -5.0 \\
Overall balance & -3.1 & 6.8 & -4.4 \\
Financing & 3.1 & -6.8 & 4.4 \\
Net international reserves & 9.2 & 0.6 & -0.7 \\
Gross reserves (- increase) & 5.1 & 1.5 & -1.4 \\
IMF credits & 0.0 & 0.0 & 1.0 \\
Short-term liabilities & 4.1 & -0.9 & -0.3 \\
Arrears & 2.7 & -0.1 & -2.9 \\
Debt deferral & 0.0 & 0.2 & 7.9 \\
Otherc & -8.8 & -7.5 & 0.1 \\
\hline
\end{tabular}

Sources: International Monetary Fund (1992a) for 1990 only, and government of Russia.

a. Excludes inter-republican trade.

b. Figures for 1992 are estimates.

c. For 1990 and 1991, primarily reflects the financing of Russia's trade surpluses with other republics.

THE BALANCE OF PAYMENTS CRISIS. Another part of the macroeconomic legacy is the balance of payments crisis. Table 5 indicates the severity of this problem. This crisis has three roots. First, oil and gas exports, the largest foreign exchange earners, have been on a steep downward trend in recent years. Total oil production in Russia has de-

than 25 percent between 1985 and 1990 . No commentator would venture to say that real incomes have risen in the Soviet Union. Nor should they claim that real incomes would actually fall if the same real wage increase were to be eliminated by a future liberalization of prices. If prices are liberalized in the Soviet Union, we would not be surprised to hear a chorus of voices bemoaning the sharp drop in real incomes, repeating the incessant and incorrect assessment of price liberalization in Poland." (Jeffrey Sachs and David Lipton, “ 'Shock Therapy' and Real Incomes: Eastern European Reforms," The Financial Times, January 29, 1991, p. 17.) 
clined from 560 million metric tons (mmt) in 1989 to $516 \mathrm{mmt}$ in 1990 , and from $461 \mathrm{mmt}$ in 1991 to a projected $395 \mathrm{mmt}$ in $1992 .{ }^{16}$ Dollar earnings on oil and gas exports from Russia to countries outside the Commonwealth of Independent States (CIS) will have declined from around $\$ 37$ billion in 1990 to a projected $\$ 17$ billion in $1992 .{ }^{17}$ The downward trend results from the depletion of Russian oil fields, inadequate techniques for secondary recovery from oil and gas fields, and large losses in pipeline transport, where leakages can result in losses of 10 percent of shipments. This downward trend is projected to continue unless it can be halted by several billion dollars of new capital investment.

Second, the Gorbachev regime exhausted Russia's international creditworthiness by the rapid accumulation of around $\$ 65$ billion of foreign indebtedness, mostly in a six-year period. The regime also virtually depleted Russia's foreign exchange reserves, including the stocks of monetary gold. Access to credits from commercial sources dried up in 1990 to 1991, when the Russian foreign exchange bank, Vnesheconombank, started to fall significantly into arrears on trade credits. Official credits also were effectively cut off by mid-1991. The result was a negative net resource transfer, leading to a collapse of foreign exchange reserves and a rise in arrears on debt repayments. ${ }^{18}$ During 1990-91, the Soviet Union spent $\$ 9.7$ billion of international reserves, including gold, in debt service. When the Gaidar government began its economic reform program, Russia's gold stock had fallen to about $\$ 2.6$ billion and the foreign exchange reserves of the Central Bank of Russia (CBR) were only a few hundred million dollars, or enough to cover only a few hours of imports! ${ }^{19}$

16. Government of Russia.

17. IMF (1992a, table 24, p. 77) and goverment of Russia.

18. Some analysts have argued against Western assistance to Russia, supporting their point with the observation that $\$ 40$ billion to $\$ 50$ billion in loans during 1991 was wasted. (See, for example, Henry Kissinger, "The Question of Aid," Washington Post, March 31, 1992, p. A17.) Data from the European Community show that Western loan commitments to the FSU may have totaled about $\$ 57$ billion in 1990 and 1991. Disbursements in the twoyear period, however, were about $\$ 26$ billion. Moreover, there is little mystery about what became of the funds. Debt service payments were on the order of $\$ 40$ billion (including the repayment of short-term debts). The net flow of minus $\$ 14$ billion was paid for mainly by a run-down of reserves of $\$ 9$ billion, a small trade surplus, and an increase in arrears of roughly $\$ 3.5$ billion (Government of Russia).

19. Government of Russia. 
Just at the time of the appointment of the Yeltsin-Gaidar government in late October 1991, following the failed putsch, the Group of Seven industrialized democracies (the G-7) pressured Russia into signing a Memorandum of Understanding (MOU) regarding Soviet debt, in which Russia and the other signatories accepted "joint and several responsibility" for the debt and agreed to pay interest due. In fact, and totally predictably, Russia has not been able to fulfill the obligation: arrears to the official creditors (of the Paris Club) and to private creditors (the commercial banks and suppliers) have mounted rapidly in 1992. The MOU was a (typical) empty gesture of G-7 debt management that has muddied the waters, rather than resolving problems.

The third part of the balance of payments crisis has been the steep collapse of trade among the countries of the former Council for Mutual Economic Assistance (CMEA). In part, the collapse has resulted from a decline in Russian sales of oil and gas to Eastern Europe. In part, exports of military equipment to the region have declined. An estimate by Herbert Wulf suggests that USSR military exports in constant 1990 prices fell from about $\$ 15$ billion in 1989 to less than $\$ 5$ billion in $1991 .{ }^{20}$ A third problem is the failure to establish a working payments mechanism for trade with Eastern Europe in 1991. Overall, Russia's exports to the CMEA countries declined steeply, from an estimated $\$ 40.1$ billion in 1990 to $\$ 15.9$ billion in $1991 .{ }^{21}$

The overall balance of payments crisis has produced a dramatic collapse of Russian imports, as seen in table 5. As the Soviet Union disintegrated, Russia's imports fell from $\$ 82.9$ billion in 1990 to only $\$ 45.1$ billion in 1991, an astounding drop of 46 percent. ${ }^{22}$ The collapse has not been arrested in 1992. Despite IMF projections in April that exports and imports would stabilize in 1992, the balance of payments crisis has intensified. Mainly because of difficulties in the production of energy, exports continue to decline, and as a result, imports in the first half of the year were $\$ 36$ billion at an annual rate (a further 20 percent decline from the low import level of 1991). ${ }^{23}$

20. Wulf (1992, figure 4, p. 6). Wulf's estimate does not break down how much of this decline was caused by a drop of exports to Eastern Europe, versus the Middle East and other areas.

21. IMF (1992a, table 23, p. 76).

22. $\operatorname{IMF}(1992 \mathrm{a}$, table 24, p. 77) and government of Russia.

23. Government of Russia. 
The fall of exports and the withdrawal of financial credits has led to an intense scarcity of foreign exchange in Russia, now reflected in the collapse of the real purchasing power of the ruble vis-à-vis foreign exchange. Consider, for example, an average worker's ability to purchase dollars (or dollar-priced items) using ruble wage earnings. The average worker earned about 5,900 rubles per month in August 1992. Because dollars are so scarce and therefore so expensive, this wage translated into only about $\$ 30$ per month at the floating exchange rate of 205 rubles per dollar that prevailed at the end of August.

The cutback of imports is one important cause of the ongoing collapse of industrial production. (The other main cause is the necessary and desirable cutback in the output of the military-industrial complex.) In 1991, industries were subjected to sharp cutbacks in centralized allocations of imported inputs, including raw materials, intermediate goods, and spare parts; this contributed to the 9 percent fall in GDP, compared with $1990 .{ }^{24}$ In 1992, the intense shortage of foreign exchange is hitting enterprises through market mechanisms, rather than through central allocations of foreign exchange. Specifically, enterprises cannot afford to purchase imported inputs at the free market exchange rate because they cannot pass the high costs of imported inputs on to their domestic consumers, in view of average wages of about $\$ 30$ per month. Similarly, enterprises cannot afford to purchase domestically produced tradable goods, such as metal ores, because the prices of such goods are now being drawn up toward world market prices in the same way as imported goods.

MONETARY DISARRAY. Another part of the macroeconomic legacy was a monetary system in disarray. Most importantly, during 1991, each republic in the former Soviet Union established its own central bank, which began issuing ruble bank credits alongside the credits of Gosbank, the central bank of the Soviet Union. Ruble credits issued by one central bank were accepted as a means of payment throughout the country. This distressing situation promoted extremely rapid money growth in which republican governments and enterprises could look to their new central banks as a fairly automatic source of credit.

The situation was exacerbated by three conditions. First, throughout 1991, republics struggled with the Soviet central government over politi- 
cal legitimacy and control of resources. Therefore, republican central banks and parliaments bid for the loyalty of enterprises, particularly in the military-industrial complex, through the ready granting of credits at very low nominal interest rates and highly negative real interest rates. Second, during 1990 and 1991, banks established by state enterprises greatly proliferated and were licensed by republican authorities with no regard to capital adequacy, conflict of interest, or other prudential concerns. The republican central banks (particularly in Russia) fed these new banks by granting them refinance credits for on-lending, largely to the enterprises that owned them. The number of banks operating in Russia went from one monobank-Gosbank-in 1988, to more than 1,500 commercial banks with more than 2,000 branches by the end of $1991 .{ }^{25}$

Third, there was little technical understanding and no tradition of an active monetary policy to limit credit growth. Throughout the period of central planning, credit flows were subordinated to physical commodity flows as assigned in the plan. In other words, enterprises were automatically given the monetary resources to pay for inputs assigned to them in the plan. The idea that bank credit should be limited to restrict the overall growth of the money supply simply did not exist until 1992 .

The fiscal and monetary crisis, the wage explosion, and the collapse of the ruble all contributed to an enormous excess demand for goods during 1991. As shown in table 4, the money supply (M2) as a percent of GDP was in the range of 60 to 70 in 1991. This condition, together with the large budget deficit and the high wage levels, stoked total demand in the economy. This excess demand resulted in intensifying shortages, a collapse of the official trading system, black market prices many times official prices, and a descent into primitive barter relations in the economy.

The excess demand was temporarily reduced in early 1991 by administrative price increases (as opposed to price liberalization), and by a partial monetary confiscation, undertaken by the last Communist prime minister, Valentin Pavlov. The monetary confiscation removed R4 billion, representing about 3 percent of the ruble money supply; ${ }^{26}$ then, as is typical of weak communist governments, Pavlov agreed to give back the money in various forms of compensation. After breaching one of the 
most fundamental contracts with the public through the confiscation of currency, the Pavlov measure was largely ineffective. At nearly the same time, many consumer prices were raised by a factor of three. This succeeded briefly in restoring foodstuffs to the official retail outlets. The ongoing increase in credits and wages, however, quickly led to renewed shortages, which were exacerbated by hoarding in anticipation of further official prices increases. By the end of 1991, the official supply system had completely collapsed. The overall situation resembled that described by Keynes:

If a man is compelled to exchange the fruits of his labors for paper which, as experience soon teaches him, he cannot use to purchase what he requires at a price comparable to that which he has received for his own products, he will keep his produce for himself, dispose of it to his friends and neighbors as a favor, or relax his efforts in producing it. A system of compelling the exchange of commodities at what is not their real relative value not only relaxes production, but leads finally to waste and inefficiency of barter. ${ }^{27}$

State and municipal grain reserves were rapidly depleted, as foodproducing regions hoarded food or bartered it directly with enterprises producing consumer goods, rather than selling it to the official procurement agencies at unrealistic official prices. Some regions actually exported grain to neighboring countries (such as Iran) to earn the vastly higher black market prices, at the same time that emergency food shipments to the Soviet Union were starting. Fear of hunger in the winter of 1991-92 became widespread. Of course, the descent into barter was widely misinterpreted in Russia and the West as a production breakdown, rather than a monetary breakdown. Western aid agencies spoke of sending missions to help the Russians with improved distribution of food, better bakeries, and better storage facilities, rather than with price liberalization and monetary control.

The new Gaidar economic team directed its attention to the monetary character of the shortages by putting the emphasis on price liberalization and monetary restriction. Interestingly, key advisors harkened to the grain shortages that afflicted the provisional government of Alexander Kerensky between February 1917 and the October Revolution. ${ }^{28}$ Then too, the combination of price controls and inflationary finance had resulted in a breakdown of the availability of bread in the official supply

27. Keynes (1920, p. 240).

28. Mau (1992). 
networks and extensive hoarding in the countryside. Kerensky made the disastrous decision to address the problem by attempting, fruitlessly, to arrange barter deals between agricultural regions and urban enterprises. Labor unrest in the face of food shortages and agricultural discontent in the face of low fixed prices for grain contributed to the onset of the Bolshevik Revolution.

\section{The Reforms in the Short Run}

The economic reform program introduced in January 1992 has five main pillars. The first and most immediate aim is to end Russia's financial chaos and make the ruble a usable and well-functioning money for both commerce and finance. Gaidar reckoned correctly that without the rehabilitation of the ruble, Russia would not be able to stabilize the macroeconomy, proceed with the creation of a market economy, or begin the painstaking structural adjustments that would be required in the coming years.

The second task is market liberalization, including the sharp cutback of state orders, the opening of the economy to trade, and the construction of a legal system for private property and market-based activity. The third task is rapid privatization. The fourth task is the construction of a social safety net including, most urgently, a system of unemployment compensation. The fifth task is the design of an appropriate industrial policy to reduce the scale of the military-industrial complex and ease the transition to civilian uses of the vast resources in that sector.

The first two tasks, stabilization and liberalization, are the principal focus of the reforms to date and are the focus of our discussion as well. Dramatic progress is already underway, however, on the longer-term aspects of the reform, mainly privatization and social policy-areas that we stress are crucial to the success of the reforms, but that are beyond the scope of this paper, except for the following brief overview.

The Gaidar economic team has moved swiftly to prepare for privatization, recognizing how delays in privatization in Poland and elsewhere have undermined stabilization efforts and forestalled structural adjustment. Privatization of small-scale enterprises began at the start of the year, and privatization of most large-scale enterprises was slated to begin in late 1992. In preparation for mass privatization, industrial enter- 
prises covering nearly three-quarters of state industrial capital (by book value) are to have corporatized-to have converted to joint stock company form-by October 1, 1992. Under mass privatization, the shares of these companies will be privatized in several blocks. Some shares will be distributed either for free or at deeply discounted prices to workers and managers; some shares will be auctioned to the public through vouchers; and some shares will be sold in cash auctions.

The share distribution techniques are intended to improve the system of corporate governance, as several groups of owners come to exercise influence over company management. Workers will acquire shares; however, it is unlikely that worker ownership will lead to excessive control by insiders because workers' shares will be held individually (rather than collectively) and will be freely transferable. The privatization vouchers, distributed to the public on October 1, 1992, can be exchanged directly for shares, but it is expected that many of the vouchers will be placed in newly formed investment funds. These funds should attract voucher-holders because they will offer a diversified portfolio; managers of the investment funds, in turn, should then be in a position to actively monitor the companies in their portfolios.

As for social policy, the key work of setting up an unemployment benefits system has been undertaken during the year, but unemployment itself remains well below 1 percent of the labor force. ${ }^{29}$ As for industrial policy, as of September 1992, the government had only begun to outline its strategy for priority sectors (agriculture, energy, and military conversion), in a program of targeted assistance (linked to foreign financial assistance from the World Bank, the European Bank for Reconstruction and Development (EBRD), and other sources) that will begin in 1993.

The first step toward rehabilitating the ruble was to eliminate the huge monetary overhang. Gaidar decided to attack the problem through the liberalization of prices and economic activity, combined with restrictive monetary and fiscal policy. With this approach, market forces rather

29. Brainerd (1992b). The Federal Employment Service (FES) of Russia is charged with developing an employment policy and managing the unemployment compensation system. As of July 1992, 250,000 workers, or 0.3 percent of the labor force, were registered as unemployed. Unemployment compensation is available for a registered unemployed person who has worked for at least twelve weeks before unemployment. Benefits may last up to one year. During the first three months, the benefit is 75 percent of the previous wage; during the next four months, the ratio is 60 percent of the previous wage; thereafter, the ratio is 45 percent of the previous wage. For further details, see Brainerd (1992a, 1992b). 
than the government would determine the rise in prices needed to reduce real money balances to a level consistent with monetary equilibrium. At the beginning of 1992, most prices were freed from administrative control and allowed to rise freely. (The main exception to price liberalization is energy, which regrettably remains under administrative control. $)^{30}$ At the same time, a presidential decree on January 29, 1992, declared that all economic activity is permitted unless expressly forbidden, standing on its head the Stalinist dictum to the contrary. ${ }^{31}$ Consumer prices rose by 250 percent in January 1992, with the prices of many goods rising ten times or more..$^{32}$ In the first three months of the year, the monetary overhang was eliminated, the ruble money supply dropped to the range of 10 to 15 percent of GDP, and commodities started to flow once again through formal supply networks (rather than through black markets). ${ }^{33}$ Inflation has subsequently declined, but was still around 9 percent per month by August 1992. While the liberalization of prices certainly eliminated Russia's monetary overhang and restored the flow of commodities in the state retail outlets, stabilizing prices re-

30. Energy prices were raised administratively at the outset of the reforms, rather than liberalized; a second adjustment was made in May 1992; and a further liberalization was announced in mid-September. In the summer of 1992, the price of a ton of oil was about $\mathrm{R} 2,000$, or about $\$ 10$ to $\$ 20$, or 10 to 20 percent of the world price. The failure to liberalize oil prices derived from the general reluctance to allow a more dramatic fall in production in heavy industry. Russia has suffered greatly for this decision. Energy that might have been exported to alleviate the balance of payments squeeze was squandered to produce goods that no one wanted or needed. In addition, the budget went without a major potential source of revenue in the midst of a stabilization crisis. The September liberalization is intended to allow producers to negotiate prices freely, and (given the export regime) is expected to lead to an increase in crude oil prices to about R5,200.

31. As one Russian wit put it, "In the Soviet Union, almost everything was forbidden . . . and those few things that were permitted were compulsory."

32. IMF (1992b, p. 18). The large initial increase in prices came as a surprise to many observers, and, in particular, to the International Monetary Fund (IMF), which had repeatedly argued that the monetary overhang was modest in size and that the price increase would be smaller. In fact, the IMF consistently underestimated the monetary pressures throughout Eastern Europe, and did so again in Russia. The IMF and others calculated in early 1991 that a 45 percent price increase would eliminate the overhang (Joint Study, 1991, p. 392); later the Fund suggested that part of the overhang probably had been eliminated by inflation over the course of 1991 .

33. Needless to say, shortages intensified for the commodities that remained controlled. In particular, the queues for milk lengthened so drastically that much of the population at first did not experience a net reduction in queuing. In reaction, the government removed the remaining controls in the course of several months, leaving municipalities free to impose local controls if they could finance the requisite subsidies. 
quires control over the subsequent creation of money. The main challenge facing the Russian authorities after the liberalization has been to slow dramatically the rate of growth of the ruble money supply and, in that way, bring down the rate of inflation and strengthen the external value of the ruble.

The record so far has been mixed. Monetary policy prevented the initial jump in prices from turning into a runaway inflation, and inflation fell gradually to about 10 percent per month by July. The extreme breakdown in the use of the ruble was reversed and monetary conditions made possible a return of goods to the shops. At the same time, price and exchange rate stabilization were not achieved. And as is explained below, credit policy has been relaxed to a dangerous degree in recent months, presenting a real risk of destabilization.

Price liberalization and macroeconomic measures were combined with other far-reaching, though partial, steps of market liberalization. Additional liberalization measures have begun to open up internal trade to individuals and enterprises, scaled back state orders (by which the government requires deliveries of goods at administratively set prices rather than contract prices), and set out the legal foundation for private sector economic activity. Where state orders remain, compliance is generally low, mainly because no effective form of compulsion exists, and because market opportunities now provide a strong diversion.

Market liberalization is still far from complete, and the steps that have been taken, albeit large, still fall short of the comparable actions taken in Eastern Europe. ${ }^{34}$ Most trade in manufactured goods has been liberalized, but extensive restrictions remain on the export of most raw materials and some semifinished products (in a costly attempt to protect domestic industries that use raw materials). A significant proportion of interenterprise distribution remains subject to central allocation, at least formally. State trading organizations are still restricted in their retail markups to 25 percent above costs, a practice that undoubtedly continues to restrict the flow of some goods in state retail outlets. ${ }^{35}$ And even where the federal government has removed barriers, regional and local governments often intervene in trade and impose bureaucratic restrictions on entry, thereby encouraging corruption and kickbacks. 
One area where the state order system has continued to pose a serious obstacle is in trade among the newly independent states. Rather than creating mechanisms for market-based trade between states at the start of the year, trade protocols were negotiated with each state to govern nearly all interstate trade. These protocols were naively conceived, and predictably have not been fulfilled. More distressingly, market-based trade has not adequately substituted for the debacle of the trade protocols, largely because of the failure to develop satisfactory monetary relations among the new states (see below). While data on interstate trade are unreliable, a collapse of trade volumes appears to have occurred so far this year.

\section{Stabilization Policy}

We now examine the stabilization crisis more closely, looking first at fiscal policy and then at monetary policy. From the outset of the reform, the main goal of fiscal policy has been to reduce to a very low level the amount of money being issued to support the budget deficit. To achieve this goal, the Gaidar government faced enormous obstacles, including the heritage of the communist fiscal system, the complete financial collapse experienced last year, and the weakening of traditional revenue sources that is inherent in the shift to a market economy. With revenue sources dropping sharply, the key steps were sharp cuts in spending on subsidies, armaments, and budgetary expenses for enterprise investments and the introduction of a 28 percent value added tax (VAT).

Despite the obstacles to fiscal control, the government's strategic goal of reducing the inflationary finance of the budget was largely achieved in the first half of 1992 . The domestic finance of the budget was reduced from about 20 percent of GDP in 1991 to about 2 percent of GDP in the first half of $1992 .{ }^{36}$ Viewed another way, monetary finance of the budget deficit raised the beginning-of-the-year stock of high-powered money by only 17 percent. The reduction in inflationary finance was partly achieved by a buildup of domestic arrears, and much more importantly, of administrative limitations on spending that had been ap-

36. IMF (1992a, p. 70) and government of Russia. The government also provided unbudgeted subsidies on centralized imports by selling these imports at domestic prices that did not reflect the official exchange rate. These imports, and hence the subsidies, were financed by credits from Western governments and did not result in the creation of rubles. 
proved by the parliament. These administrative measures were taken in view of tax revenues that came in much below target. In the third quarter, however, the government made extensive concessions to industry and certain regions, leading to much greater money financing of the budget. The final data are not yet in, but it appears that the money financing may have amounted to as much as one third of quarterly GDP. If this new direction of monetary policy were to continue, the gains will be completely dissipated by hyperinflation.

Fiscal policy will remain a deep source of crisis for several years, until a new fiscal basis for the state can be consolidated. With the collapse of the Soviet state has come an abrupt collapse of revenues, from around 37 percent of Soviet GNP in 1990 to around 24 percent of Russian GNP in the first quarter of $1992 .{ }^{37}$ This is largely a desirable trend as the state removes itself from deep intervention in the economy. However, as we have witnessed in Eastern Europe, the collapse of revenues can easily outpace the politically achievable cutback in expenditures, especially when the newly democratic state is facing strong demands for increased social spending.

To avoid a chronic fiscal crisis, progress is needed on two fronts. First, the VAT and new income taxes covering the private sector must be vigorously implemented to replace the disappearance of the old mainstay of the system, the turnover and profits taxes on state enterprises. Second, the government must move toward a new fiscal federalism in which a much greater share of governmental responsibilities are allocated to local governments, with local taxes providing the basis of finance. It is almost surely the case that local governments will increasingly resist the transfer of tax revenues to the center. (Already, key regions have had great success in obtaining tax exemptions.) Rather than fighting this inevitable trend, the federal government would be wise to devolve many of its responsibilities to the regions.

\section{Monetary Policy}

The monetary overhang that Gaidar faced at the end of 1991 was created not only by the monetization of the budget deficit, but also by the extension of a huge amount of cheap credit to state enterprises by the

37. See Alexashenko (1992, table 5, p. 56). 
Central Bank of Russia (CBR) in the course of 1991. As the Soviet Union disintegrated, Gosbank of the Soviet Union provided the government the credit it needed to cope with the collapsing state finances. The CBR, eager to find a role for itself, became the champion of the emerging commercial banking sector and its state enterprise clients. With wholesale price inflation at about 140 percent in 1991 (measured from the beginning to the end of the year) ${ }^{38}$ and CBR rediscounts charging interest rates from 6 to 9 percent, ${ }^{39}$ the CBR managed to extend R297 billion in credit (amounting to 58 percent of the beginning-of-year stock of ruble money) to the nongovernment sphere, which was willingly scooped up by the commercial banks.

With the demise of the Soviet Union, the closure of Gosbank, and the emergence of new central banks in each independent state, stabilizing the ruble requires converting the Central Bank of Russia into an effective monetary authority for the ruble area. This would entail several steps; some of these measures have been taken, while others have not.

The CBR began the year by ending its practice of extending unlimited credits to commercial banks. The central bank raised its finance rate from 6 percent to 20 percent in January 1992, and after a few months to 50 percent and eventually 80 percent, and phased in a 20 percent reserve requirement for short-term commercial bank deposits. These changes, although inadequate in the face of the stabilization problem confronting Russia, represented a revolutionary change in the management of the monetary system.

What was also needed, following the elimination of the monetary overhang, was a credit program, backed up by realistic interest rates, that would limit the creation of rubles, maintain monetary balance, and support the stabilization of prices and the exchange rate. With a tight credit program, state enterprises would be forced to finance themselves, rather than rely on an unending stream of credits. To acquire rubles, enterprises would be forced to liquidate inventories, to dip into bank balances, and (given the overly depreciated exchange rate for the ruble) to repatriate foreign currency holdings and boost exports. Given these considerations, a tight credit program was key to ending the shortage economy, getting goods back on the shelves, and ending the extreme weakness of the ruble.

38. IMF (1992a, p. 9).

39. IMF (1992a, p. 18). 
The industrial sector, however, clamored for credits, arguing that the government's policies had unduly restricted liquidity. The industrialists pointed out that the real value of working capital and other credits outstanding had fallen sharply in the first few months of the year and argued that this jeopardized their ability to produce. They cited the rapid accumulation of interenterprise arrears as evidence that central bank credit policy was too tight-despite the fact that the arrears arose for many reasons, including a breakdown of the payments system and the simple fact that many enterprises in heavy industry, and particularly in the MIC, simply lacked customers.

The CBR attempted to chart an intermediate course, neither committing itself to establishing price stability nor adopting a policy of restoring enterprise liquidity. The failure to adopt a well-defined, disinflationary credit program-which might have served as a framework for the many individual credit decisions that arose-left the CBR vulnerable to the steady drumbeat of demands for credits to industry and other priority sectors coming from the parliament and the public. The result was the provision of $\mathrm{R} 457$ billion in finance credits from the CBR to commercial banks over the first half of the year, an amount approximately equivalent to the stock of high-powered money at the beginning of the year. These credits exceeded by far the monetization of the budget deficit and were mainly responsible for the slow progress in bringing down the rate of inflation, which has for the most part been in the range of 10 to 30 percent per month.

The credit creation has certainly accelerated in the third quarter. Starting in July, industrialists stepped up the pressure for credits to support their enterprises, many of which were proving unable to meet the test of the market. These industrialists found willing allies in the CBR, and, in the third quarter of the year, the credits extended exceeded the total amount of base money existing at the beginning of the quarter. The result, predictably, has been a rise in the rate of inflation and a collapse in the external value of the ruble, to a point where a U.S. dollar now costs nearly R400. Because of this credit policy, the earlier gains have been reversed and Russia now faces a real risk of hyperinflation.

MANAGING THE RUBLE AREA. While CBR credit expansion within Russia has been the main obstacle to stabilization, the job of the central bank is complicated by several other factors, the most important of which is the continuing issuance of ruble credits by the central banks of 
the states of the FSU. For monetary policy to be effective and for the stabilization effort to succeed, there must be a single monetary authority with control over the instruments of monetary policy. When the reforms began, each of the fifteen independent states had a central bank with the ability to exercise an important degree of control over monetary policy. Moscow maintained physical control over the printing presses for currency issue, but many states introduced coupons or other currency substitutes. Moreover, under the interstate payments system that prevailed in the first half of 1992, bank credits created outside of Russia could be spent in Russia, resulting in the monetization of Russia's trade surpluses and the importation of demand pressures from neighboring states.

In our view, there is no realistic possibility of controlling credit in a system in which several independent central banks each have the independent authority to issue credit. The reason is simple. Pressure is overwhelming in each of the states to "free ride" by issuing ruble credits at the expense of the rest of the system. It is a nearly self-evident proposition that a single currency area should have a single bank of issue. As Milton Friedman argues:

The key feature of a unified currency area is that it has at most one central bank with the power to create money - "at most" because no central bank is needed with a pure commodity currency. The U.S. Federal Reserve System has twelve regional banks, but there is only one central authority (the Open Market Investment Committee) that can create money. [Similarly,] Scotland and Wales do not have central banks. ${ }^{40}$

In our view, each of the independent states should quickly introduce its own currency by substituting new banknotes (or coupons) for the rubles in circulation in the state, and by redenominating bank balances, contracts, wages, and prices in the new currency at a uniform exchange rate between the ruble and the new currency. Trade between the state and Russia could continue to be conducted in Russian rubles, but the state would have to earn the rubles by its own exports or by explicit credits from Russia, or get them by selling foreign exchange for rubles. If the state wanted to maintain close monetary harmonization with Russia, it could peg its currency to the ruble. Otherwise, the state could let its currency float against the ruble (and perhaps peg it to something else, such as a Western convertible currency).

40. Friedman (1992, p. 242). 
When faced with the question of how the ruble area should be managed, the IMF has been extremely unhelpful. Convinced at first that the best way to preserve interstate trade was to retain as large a ruble area as possible, the IMF in early 1992 urged all the independent states to remain in the ruble area. Once the inadequacy of budget and credit policies in certain states became clear, the IMF worried that new currencies might be unstable and encouraged the states to delay the introduction of their new moneys, ignoring the inescapable implication that macroeconomic policy mismanagement outside of Russia would only serve to undermine the ruble stabilization effort! Finally in April 1992, the IMF proposed a system for managing the ruble area that would have permitted each central bank to issue rubles and relied upon multilateral negotiations to reach an acceptable credit plan. Russia rejected this proposal as inadequate. Nonetheless, the IMF continued to advise other states to delay introducing their own currencies, and has provided almost no technical assistance on this critical issue.

In the absence of helpful Western guidance, the ruble area issue came to a head in June as several independent states proceeded with plans to print local currencies (that would substitute for the ruble) and to extend ruble credits. The most troubling news was Ukraine's announcement in June of 1992 of its intention to proceed-unilaterally and without consultation-on an enormous credit expansion (between R300 billion and R600 billion of high-powered money), in order to settle interenterprise arrears. This massive amount of credit issue threatens to worsen greatly the inflation in Russia unless the moneys of Ukraine and Russia are quickly separated.

The Russian authorities have responded by beginning a process that will force a separation of the Russian ruble from the moneys of other independent states. A decree in July halted the automatic crediting of independent states running trade deficits with Russia and established that Russian goods could only be purchased with ruble deposits in Russian banks. Ukrainian importers could not buy Russian goods with Ukrainian bank deposits granted by the Ukrainian central bank. Instead they now have to acquire ruble deposits in Russian banks from Ukrainian exporters, who have been credited for their export shipments. Fully instituted, this system would create a truly Russian ruble and insulate Russia from the credit policies of other independent states. 
Estonia demonstrated that this process can be planned and completed in a few weeks. (The IMF originally urged the Estonians to delay until 1993; now the IMF rightly heralds the steps taken by Estonia.) In early June, Estonia replaced rubles with a new banknote, the kroon, at a rate of 10 rubles per kroon. The kroon was pegged to the deutsche mark (DM) at a fixed rate of 8 kroon per DM (which was slightly more depreciated than the black market price of 75 rubles per DM) ${ }^{41}$ All other prices and accounts were converted at the same rate. Trade with Russia now continues in both hard currencies and rubles. A ruble market should develop in Estonia's capital of Tallinn, in which Estonian exporters to Russia sell their ruble earnings to would-be importers for kroons. The kroon-ruble rate floats freely, and the kroon has appreciated to 20 rubles per kroon as of September 1992. ${ }^{42}$

RUSSIAN FINANCIAL SUPPORT TO THE OTHER REPUBLICS. One of the great burdens on the Russian economy has been the implicit or explicit subsidization of the other republics. The main form of subsidization has been the exchange of energy products from Russia for manufactured goods from the other republics at terms of trade that substantially underpriced the energy in comparison with world markets. A second form of subsidization has been the extension of credits to other republics through the banking system to finance chronic trade deficits of many of the republics vis-à-vis Russia. A third form of subsidization has been the provision of foreign exchange to other republics, at a price in terms of rubles far below the market price. Only the third form of subsidization has been substantially eliminated this year.

The Gaidar economic team announced its intentions to eliminate the heavy transfer burdens on Russia at the start of the reforms, but in fact, Russia has continued to bear an enormous cost vis-à-vis the other republics. Barter trade agreements between Russia and the other states were maintained in 1992, contrary to the overall thrust of the reforms. While this barter system has largely collapsed in practice (for want of enforcement and financial mechanisms), Russia has continued to oblige its energy producers to deliver oil and gas to the other states at energy prices far below world levels. In some cases, these oil shipments have in fact

41. Hansson and Sachs (1992).

42. Hansson and Sachs (1992). 
been reexported to world markets, allowing enterprises in the other states to capture an enormous rent.

Russia also continues to provide enormous credits to the other republics to purchase Russian output. The CBR has credited the accounts of the republican central banks, which in turn have credited the accounts of enterprises and banks in the independent states. These credits amount to more than one-third of the overall increase in Russian highpowered money during January-June 1992, almost half of which was extended to Ukraine alone. ${ }^{43}$

RUBLE CONVERTIBILITY. As conceived by the reformers, the Russian monetary reforms also aimed to make the ruble a usable currency in international trade and financial transactions. Currency convertibility was seen as the necessary first step in a process that would end Russia's economic isolation and lead to integration with the world economy. By ending the chronic overvaluation of the ruble, exports would be stimulated and imports would be available on a market basis. Domestic prices of import-competing goods would be disciplined by world market prices. In the long run, convertibility would enhance the inflow of goods, capital, and technology, and thereby accelerate the process of economic transformation and development.

Under the communist economic system, the official exchange rate was consistently maintained at an overvalued level and foreign exchange was rationed. At the same time, the domestic economy was insulated from the influences of international markets through a system of adjustable trade equalization taxes and subsidies that removed the difference between fixed domestic and world prices for all enterprises engaging in international trade. As a result, domestic prices bore no particular relationship to world prices and no rationality existed in Russia's international trade pattern. The system imposed a heavy anti-export bias because of the currency overvaluation.

The reforms of 1992 have moved Russia toward convertibility. First, trade equalization taxes have been eliminated. However, energy and raw materials prices are still kept below world prices by export taxes and quotas. These taxes and quotas are to be eliminated in the coming year,

43. Government of Russia. One partial offset to these credits has been arrears in payments by Russian enterprises for purchases in other republics. If such arrears are factored in, Russia's net extension of credit is somewhat lower. The exact amount is unknown, but it is almost surely still very significant. 
which will force domestic energy prices to move up to world levels. Second, the ruble has been permitted to float in a twice-weekly interbank auction market, where enterprises may buy foreign exchange to obtain imports. For the first half of 1992, several exchange rates existed for current account transactions. On the export side, the CBR maintained a quasi-market rate somewhat more appreciated than the interbank auction rate and demanded that energy and raw materials exporters surrender foreign exchange at the punitive rate of 50 percent of the quasi-market rate. ${ }^{44}$ On the import side, the central bank continued to supply foreign exchange for various crucial "centralized imports" at a price far below the market exchange rate (on the order of one-sixth of the market price) ${ }^{45}$ In this way, imports of grains, other foodstuffs, and some other consumer goods were enormously subsidized.

On July 1, the CBR moved to unify the exchange rate system by beginning to set the official exchange rate at the level prevailing in the most recent auction and by eliminating all surrender by exporters at belowmarket rates. The government also committed to end the subsidization of centralized imports through below-market exchange rates, although it declared its intention to continue some subsidies through the budget. Foreign enterprises were also guaranteed the right to repatriate profits at the market exchange rate. With these moves, Russia established current account convertibility for the first time since 1917. Exporters are in principle required to repatriate foreign exchange earnings to Russia, although they may hold some of these earnings as foreign exchange accounts in Russian banks. In fact, there is evidence of considerable capital flight, with enterprises holding large deposits offshore.

While convertibility will boost exports and rationalize imports, the exchange rate remains deeply undervalued by any plausible measure of productivity or purchasing power; the dollar value of industrial wages was about $\$ 30$ per month at the end of August 1992. Moreover, the nominal value of the ruble has been unstable, and since August has depreciated from R130 per dollar to nearly R400 per dollar. The weakness in the ruble stems from two factors. First, the CBR continues to grant huge credits to support Russia's industrial sector, which both fuel inflation and encourage capital flight. The currency will not strengthen apprecia-

44. $\operatorname{IMF}(1992 \mathrm{a}, \mathrm{p} .22)$.

45. IMF (1992a, p. 22). 
bly until rubles are scarce enough to encourage enterprises to supply foreign exchange in the marketplace in order to obtain money to pay wages and meet operating expenses. Second, Russia continues to face an extreme balance of payments crisis. It is the extreme shortage of foreign exchange resources that is reflected in the deeply depreciated floating exchange rate. The government's aim of pegging the exchange rate and providing a nominal anchor to the price stabilization effort will not be possible until these two factors leading to the weakness of the ruble are overcome.

FURTHER MONETARY REFORMs. Additional obstacles to the management of the banking system and the stabilization of the currency stem from the heritage of the old system. ${ }^{46}$ The first obstacle to stabilization is the lack of central bank independence, an issue we take up later. A second obstacle that has hindered the operation of the monetary system is the centrally controlled settlements system for transfers between banks, which has led to long delays in settlements among enterprises.

The third important obstacle to the management of the monetary system is the payments mechanism, with its sharp division between cash money and noncash money (deposit rubles). This mechanism was phased out in Eastern Europe in the early 1980s, but remains in Russia. In fact, two interlocking circuits for payments exist. The population pays cash for retail purchases; this cash, in turn, is channeled to enterprises for the sole purpose of paying wages to employees. Meanwhile, state enterprises use noncash money for all transactions among themselves. (Retail enterprises surrender their cash and are credited with deposit rubles, which make their way up the production stream.) The consequence of these two payments circuits is that the banking system does not serve the most basic function taken for granted in a market economy: allowing the depositor to withdraw deposits in the form of cash. ${ }^{47}$ Nor does cash serve its most basic function, as legal tender for all transactions in the economy. We have made recommendations elsewhere for ending this division and regard it as a matter of urgency.

46. The following section is based on our 1992 paper (Sachs and Lipton, 1992).

47. This convertibility of bank money into currency and vice versa is considered such a central role of a banking system that it is rarely even questioned. The primary function of deposit banks in operating the payments mechanism is to convert notes and coin into bank money and bank money into notes and coin. 
The fourth obstacle to monetary management has been the accumulation during the first half of 1992 of massive interenterprise arrears, reaching about $\mathrm{R} 3$ trillion (the equivalent of about 70 percent of nominal GDP in the six-month period). These arrears pose a great danger for the authorities because they have been widely and inaccurately interpreted as indicating the inadequacy of liquidity in the economy and have led to repeated calls for massive credits to allow arrears to be cleared.

It is now clear that many factors have combined to create the interenterprise arrears problem; we have mentioned several of these already. Final demand has fallen more than production, as heavy industry has continued to produce, even in the absence of customers. Additionally, the archaic settlements system for clearing transfers between banks led to long delays and prevented enterprises from paying their suppliers because of a lack of receipts from their own customers. The breakdown of settlements with the other independent states has been particularly severe-clearing between Russian and non-Russian enterprises can take up to two months-and may face political obstacles. Incentives to clear arrears have been nearly absent. Enterprises in arrears have been able to pay or even to raise wages, and interest charges on arrears have been negligible, creating an incentive to delay payments. Finally, from the side of suppliers, satisfactory sales-verification mechanisms have been lacking; a system of bills of exchange, letters of credit, bank checks, and so forth does not yet exist to allow shippers to guarantee that they will be paid by suppliers. And without bankruptcy mechanisms, very limited means exist to enforce debt contracts.

A strategy for solving the arrears problem should have three aims. First, it should prevent existing arrears from unduly depressing the future production of healthy enterprises. Second, it should introduce measures to stop the accumulation of new arrears. Third, it should provide a way to settle the existing arrears. The Russian government has proposed that the repayment of existing arrears be postponed for one year, with the goal of preventing these arrears from destroying future production. ${ }^{48}$

48. The arrears would be converted into formal debts under the control of the State Property Committee (GKI). Debtors would owe money to the agency, while creditors would have a claim on the agency. Payments by the agency would be limited to the amount of collections from debtors. Enterprises unable to clear their debts would be subject to bankruptcy arrangements under the agency's instigation. 
Many firms lack the liquidity needed both to pay off their arrears and to buy inputs for future production. By postponing the repayment of arrears, firms are given the opportunity to continue current production. The central bank, on the other hand, has pushed for credit increases to clear the arrears, a move resisted by the government as highly inflationary. The struggle between these two approaches is as yet unresolved. ${ }^{49}$

\section{A Summing-up of the Macroeconomic Results}

After inheriting a disastrous financial and monetary situation, the Russian government took several crucial and bold moves in an attempt to stabilize the economy and move to a market-based system. Price liberalization combined with fiscal restraint succeeded in bringing goods back to the shops and breaking the back of hyperinflation. While price stabilization was not achieved, inflation was reduced to 10 percent by July 1992, after a 245 percent monthly increase in January. The depreciation of the ruble exchange rate, which began in August 1992, resulted from the ill-advised relaxation of credit policy in the third quarter of the year, which now jeopardizes the survival of the economic team and the process of economic reform.

The government and the Central Bank of Russia faced intense political attacks from the start, with charges that the reforms had devastating effects on industrial production, living standards, and unemployment. The charges were off-base, but nonetheless they contributed to pushing the macroeconomic authorities into unsatisfactory compromises by midyear, resulting in a renewed rapid growth of the money supply, a steep fall of the exchange rate, and renewed risks of hyperinflation. Particularly inflationary policy moves were taken by the Central Bank of Russia in the third quarter of 1992 . The CBR has also failed to make sufficient headway in resolving the ruble area crisis. The bank took important steps to separate the Russian ruble from bank credit issued in other states, but then undermined the effect of this action by continuing

49. Steps are also being taken to stop the accumulation of new arrears through improvements in the settlements system for transfers between enterprises. Moreover, penalties are to be levied on enterprises accruing new arrears (including limits on wages and high interest rates on the arrears). Bankruptcy proceedings may be initiated and should be imposed on enterprises that cannot pay off the old arrears and that continue to generate new arrears. 
Table 6. The Decline in Industrial Production in Economies in Transition, 1990-92

Percent per year, except where indicated

\begin{tabular}{lrrrr}
\hline \multicolumn{1}{c}{ Country } & 1990 & 1991 & $1992^{\mathrm{a}}$ & $\begin{array}{c}\text { Cumulative } \\
\text { change, } \\
1989-92^{\mathrm{b}}\end{array}$ \\
\hline Albania & -7.5 & -43.0 & $\ldots$ & -47.3 \\
Bulgaria & -16.8 & -11.2 & -26.9 & -46.0 \\
Czechoslovakia & -3.5 & -24.7 & -10.0 & -34.6 \\
East Germany & -15.0 & -20.0 & -18.0 & -44.2 \\
Hungary & -8.4 & -21.9 & -12.5 & -37.5 \\
Poland & -24.1 & -19.6 & -3.8 & -41.3 \\
Romania & -14.3 & -21.7 & -18.5 & -45.3 \\
Russia & -2.6 & -8.0 & -20.0 & -28.3 \\
\hline
\end{tabular}

Sources: World Bank (1992); “International Economic Indicators: Central and Eastern Europe," Financial Times, September 28, 1992, p. 6; and Biuletyn Statystyczny (Monthly Statistical Bulletin), various issues.

a. World Bank projections for 1992 are used for Czechoslovakia, East Germany, and Russia. For Bulgaria, Hungary, Poland, and Romania, the 1992 figure is based on the percentage change from the second quarter of the year.

b. Cumulative change is calculated from 1989 through the most recent period in 1992 for which the data are available.

a policy of easy credits to the other states, in amounts that have contributed importantly to the large money growth this year.

The attacks on the government and the central bank have missed the point. Industrial production declined not because of an excessive credit squeeze, as widely charged, but because much of the Russian MIC simply lacks customers at this time. Russia's decline has in fact been smaller than the comparable industrial declines in Eastern Europe from 1989 to 1992, despite the fact that Russia probably requires more adjustment than the other countries. Table 6 compares the decline in industrial production in Russia and Eastern Europe. As for the claim about real living standards, we have already suggested that the declines in real living standards have been greatly exaggerated and wrongly attributed to the reforms (more on this below). Finally, the attack on unemployment is both premature and off the mark. To date, there simply has been no unemployment to speak of, because it remains well below 1 percent of the labor force. Unemployment will rise in the future, particularly in the transition period. But as we discuss below, the service sector will ultimately expand to provide jobs for workers who, inevitably, will be released from the industrial sector.

In sum, the reasons for the easing up of monetary policy are unconvincing. Given the grave dangers of hyperinflation that remain, the gov- 
ernment should spend less time worrying about artificially propping up the enterprises in heavy industry and the MIC. The overall social, political, and economic risks are simply too large.

\section{The Social and Political Context of Reform}

Many observers are deeply pessimistic about Russia's long-term economic prospects. They fear that the reforms initiated this year simply cannot be sustained. A number of reasons are offered. Some claim that the short-term dislocations of the economy are so great as to guarantee a political backlash or even social explosion. Others claim that Russia's distinctive history and the character of its people will prevent the efficient operation of a market system. Our own concerns lie elsewhere: with the risks for political instability as a result of the partial nature of Russia's political and institutional reforms.

\section{Living Standards}

We have already discussed the issue of the costs of the reforms in terms of lower living standards. In our view, these costs are exaggerated; for that reason, a generalized social explosion is unlikely to derail the reforms. Of course, particular groups (such as the MIC and hardliners in the parliament) might slow or reverse the reforms, but not because of economic upheaval. ${ }^{50}$

This point is impossible to prove precisely. Nonetheless, as former advisors to the Polish government and current advisors to the Russian government, we are struck by the similarities of broad trends in the two countries, as well as the popular interpretations of these trends. A muchpredicted social explosion never came to Poland, although the country has had many strikes and protests. The overwhelming fact is the steady, peaceful, and democratic progress of the Polish reforms-even through several national elections in which extremist parties and militant labor organizations failed to ignite popular discord.

50. One risk arises from ethnic conflicts, particularly in view of the 25 million ethnic Russians who now live in other republics. It is conceivable that nationalistic pressures to protect these ethnic Russians could boil over and help undermine the new democratic institutions. 
Poland's living standards are low, as they have been for decades under communism. What we have stressed is that Poland's alleged drop of one-third in living conditions was based on a superficial interpretation of the change in the statistical real wage at the start of Poland's reform; this neglected the existence of shortages and the fact that the wage decline was reversing a previous wage explosion. Andrew Berg and Jeffrey Sachs have attempted to judge the change in living standards by looking directly at changes in consumer purchases from 1989 to 1990, based on household expenditure surveys, rather than misleading real-wage measures. ${ }^{51}$ Berg and Sachs found that the decline in real consumption was enormously overstated and was on the order of a 5 percent drop, as opposed to a 16 percent decline in the national income accounts and a 30 percent decline in the average real wage. Bryan Roberts has recently argued that if one also takes into account the end of queuing, together with the change in consumption, the overall effect of the price liberalization in Poland was a rise in Polish living standards in 1990, not a fall. ${ }^{52}$

A survey conducted in November 1991 asked 986 Poles between the ages of 18 and 65 to assess their living conditions almost two years after the start of the reforms. ${ }^{53}$ Their responses demonstrate acceptance of the economic changes. More than four-fifths of the respondents held that their family's economic situation was the same or better than five years before. ${ }^{54}$ This was at a time when the popular press depicted the Poles as seething with unhappiness over the hardships of the reforms. Similarly, 43 percent of respondents preferred "an economy like we now have" to "a socialist economy like before the revolution," while 24 percent preferred the socialist economy, and 33 percent saw no difference. ${ }^{55}$

We do not yet have the data for this kind of study for Russia. The basic patterns will likely be the same as in Poland. However, we should highlight two points. First, even if the reforms per se do not reduce living standards sharply, the backdrop is still one of a falling trend in such

51. Berg and Sachs (1992).

52. Roberts (1992).

53. Ammeter-Inquirer (1992).

54. Ammeter-Inquirer (1992, p. 18). Nineteen percent of respondents said "much better"; 38 percent said "a little better"; 25 percent said "much the same"; 15 percent said "a little worse"; and 3 percent said "a lot worse."

55. Ammeter-Inquirer (1992, p. 18). 
key sectors as energy. An income squeeze resulting from trends that preceded the reforms might be widely blamed on the reforms themselves. Also, it is likely the case that income inequality has risen as a result of the reforms, with pensioners probably being squeezed relative to younger workers.

In addition to the concern over average real consumption levels, there is widespread fear that mass unemployment will lead to a explosion of labor unrest. Once again, these fears are exaggerated. In Poland, predictions of unemployment rates of 20 to 30 percent were widely predicted. In fact, unemployment in July 1992 was at 13.1 percent of the labor force, but it is widely accepted that around one-third of the registered unemployed workers actually have work in the private sector. ${ }^{56}$ Poland has created about 2 million jobs in small enterprises (roughly 12 percent of the labor force), mostly in the service sector. ${ }^{57}$ Simple calculations suggest that the expansion of the Russian service sector will also substantially compensate for the declines in Russian heavy industrial employment.

As a back-of-the-envelope calculation (using data for the entire former Soviet Union), note that total employment in the FSU was about 136 million workers in 1988, of which approximately 21.8 million were in heavy industry (fuels, power, metallurgy, and machine building), while about 10.7 million were in trade and distribution. ${ }^{58}$ If the share of workers in trade and distribution were to rise from 8 percent of the labor force to just 15 percent of the labor force (which would still be far below the share in typical market economies), about 9.6 million new jobs would be created in trade and distribution. That would be enough to compensate for an employment decline of 44 percent in heavy industry, which itself is likely to be an overestimate of the actual decline. Even in the best case, transitional unemployment will be substantial as these shifts take place. But this, unfortunately, is inevitable.

The concern has been voiced that job losses and job needs will not match: in some cases, company towns will have to close or shrink considerably, without scope for significant increases in jobs in nonindustrial sectors. Concerns have particularly arisen about workers in MIC enter-

56. Radio Free Europe (1992, table 3, p. 52).

57. Biuletyn Statystyczny, July 1992.

58. Kwon (1992a, p. 57). 
prises. Importantly, though, the biggest concentrations of the MIC enterprises are in the major urban areas, such as Moscow and St. Petersburg-exactly the places where new service enterprises and consumer industries are likely to develop..$^{59}$ According to Julian Cooper, St. Petersburg alone accounts for nearly one-tenth of the total MIC employment, about 700,000 workers (in shipbuilding, radio and ground-force industries, and missile and aviation industries). ${ }^{60}$

\section{Is Russia Different?}

Another key claim is that Russia is different-that liberal reforms cannot take hold there. It is true that Russia's history poses a great challenge: can a country with 1,000 years of autocratic rule, which passed swiftly from feudal institutions to communism, now move swiftly to democratic capitalism, or will social mores and attitudes block the process? Peter Reddaway recently asserted, for example, that "shock therapy" cannot work because "Russia's deeply Sovietized political culture is-and even with sustained Western assistance, will be for a decade or two-highly unsuited to free markets, entrepreneurism, privatization, and rule of law." ${ }^{61}$ Of course, social science does not really equip us to give a definitive answer. We would rather stress how little evidence there is in favor of the pessimistic view. ${ }^{62}$

First, many countries have embarked on radical market reforms from a social structure that looked a priori rather unpromising, only to overcome the "social" factors. As Henry Rosovsky noted in his scintillating study on "Japan's Transition to Modern Economic Growth, 1868-

59. Cooper (1991) reports that the top ten localities in terms of MIC employment are: Yekaterinberg; St. Petersburg (city); Moscow (city); Nizhni-Novgorod; Moscow (oblast); Perm; Samara; Novosibirsk; Tatarstan; and Udmurtiya.

60. Cooper (1991, p. 24).

61. Peter Reddaway, "Next From Russia: 'Shock Therapy' Collapse," Washington Post, July 12, 1992, p. C7.

62. Many currents of Russian intellectual thought have also stressed the "uniqueness" of the Russian character, often in justification of a revolutionary ideology. Historian Richard Pipes recalls how the "going to the people movement" of the late 19th century was predicated in part on the special, and presumably revolutionary, character of the Russian muzhik. As it turned out, as Pipes ironically notes, the failure of these intellectuals "went deeper; the 'toiling masses' gave unmistakable evidence of an acquisitive spirit of the worst bourgeois type ..." (Pipes, 1974, p. 297). In our view, that highly desirable acquisitive spirit is on view again today in Russia. 
1885 ," at the time of the Meiji Restoration "foreign observers . . were extremely pessimistic" about the prospects for Japan:

With considerable complacency they wrote: "Wealthy we do not think it will ever become: the advantages conferred by Nature, with the exception of the climate and the love of indolence and pleasure of the people themselves forbid it." Or, "The national banking system of Japan is but another example of the futility of trying to transfer Western growth to the Oriental habitat. In this part of the world principles, established and recognized in the West, appear to lose whatever virtue and vitality they originally possessed and to tend fatally towards weediness and corruption". ${ }^{63}$

These charges of indolence and corruption certainly are familiar in today's discussion. They also featured prominently in doubts raised about most of southeast Asia in the 1950s and 1960s, before that region's remarkable takeoff of economic growth. Similar charges and doubts were the staple of discussions vis-à-vis Latin America until the economic recovery of several Latin American countries in recent years.

Russia's supposed uniqueness with respect to social attitudes about the market economy is not borne out in recent survey data. Robert $\mathbf{J}$. Shiller, Maxim Boycko, and Vladimir Korobov surveyed Russians and Americans to see if they could find significant differences in attitudes to economic risk, incentives, initiative, and so on. In their hunt for "homo sovieticus," the alleged Russian species that has been rendered unable to respond to economic opportunities because of 75 years of communism, the authors conclude that "the biggest obstacles to a successful transition do not seem to lie in the basic attitudes or psychological traits held by the people in the ex-communist countries." ${ }^{64}$ Differences in economic choices between Russians and Americans seem to have much more to do with "situational differences" (incentives and institutions) than with "attitudinal differences." 65

Poland's recent experience casts further doubt on the concept of homo sovieticus, because it was also alleged that the communist period there had deadened the hand of entrepreneurship. This idea has lost currency in Poland because of the remarkable explosion of entrepreneurship since 1989. The number of registered individual proprietorships nearly doubled from 813,500 on December 31,1989 , to 1,523,400 on June

\author{
63. Rosovsky (1966, p. 132). \\ 64. Shiller and others (1992, p. 179). \\ 65. Shiller and others (1992).
}


30,1992 . The increase of 709,900 small business owners represents almost 5 percent of the working population. Total employment in these enterprises nearly doubled from $1,475,500$ to $2,800,400$, an increase of almost 9 percent of the total labor force. As for larger enterprises, the number of private commercial law partnerships (partnerships, limited liability companies, and joint-stock companies) more than quadrupled from 11,693 at the end of 1989 to 51,174 by mid-1992. ${ }^{66}$

In Russia, as in Poland, important differences occur in the economic attitudes of different age groups: younger individuals are much more prone to support the ideas of radical economic change and to be more optimistic about the future. Consider table 7, which reports the results of a January 1992 survey on Russians' attitudes toward private ownership and privatization. ${ }^{67}$ Young respondents are much more disposed to private ownership, the process of privatization, the role of foreign investors, and private land ownership than are the older respondents. Nonetheless, perhaps the striking point of the survey is the overwhelming support for the basic ideas of the privatization process. Of the total population, 65 percent prefer private to state ownership (31 percent disagree); 58 percent believe that their families will be better off if the state sells enterprises to private owners ( 23 percent disagree); 52 percent believe that their families will be better off if foreigners are allowed to buy shares in state enterprises ( 29 percent disagree); and fully 75 percent of the respondents believe that their situation will be improved by private land ownership (11 percent disagree). Ironically, it is on the question of private land ownership that the hardline Congress of People's Deputies has been most resistant to reform, despite the overwhelming public support.

Unfortunately, it is not yet possible to get an accurate description about the extent to which Russians are now entering private market activity for direct comparison with the Polish experience. According to the government of Russia, the share of the labor force engaged in state enterprises fell sharply between 1990 and 1991 , from 82.4 percent to 77.2 percent, with employment in leased enterprises, joint stock companies, joint ventures, and private organizations rising from 5.8 percent of the labor force to 10.4 percent in one year. ${ }^{68}$ We suppose that the trend is

66. Biuletyn Statystyczny, June 1991 (pp. 57-58) and September 1992 (pp. 89-90).

67. Boeva and Shironin (1992).

68. Government of Russia. 
Table 7. Russian Attitudes toward Private Ownership and Privatization,

January 1992

Responses in percent

\begin{tabular}{|c|c|c|c|c|}
\hline \multirow[b]{2}{*}{ Question } & \multicolumn{4}{|c|}{ Age group } \\
\hline & Under 30 & $30-59$ & Over 59 & $\begin{array}{c}\text { Total } \\
\text { population }\end{array}$ \\
\hline \multicolumn{4}{|c|}{$\begin{array}{l}\text { 1. State ownership is the best way } \\
\text { to run a business. }\end{array}$} & 31 \\
\hline $\begin{array}{l}\text { An enterprise is bes } \\
\text { entrepreneurs produ } \\
\text { people want. }\end{array}$ & 82 & 64 & 43 & 65 \\
\hline Don't know. & 2 & 4 & 4 & 4 \\
\hline \multicolumn{5}{|c|}{$\begin{array}{l}\text { 2. What effect will the following } \\
\text { have on your own family } \\
\text { situation if/when the } \\
\text { government: }\end{array}$} \\
\hline \multicolumn{5}{|c|}{$\begin{array}{l}\text { a. Sells state enterprises to } \\
\text { private owners? }\end{array}$} \\
\hline Better off & 75 & 57 & 37 & 58 \\
\hline Worse off & 11 & 24 & 40 & 23 \\
\hline No difference & 12 & 16 & 22 & 16 \\
\hline Don't know & 2 & 2 & 2 & 2 \\
\hline \multicolumn{5}{|c|}{$\begin{array}{l}\text { b. Allows foreigners to buy } \\
\text { shares in state enterprises? }\end{array}$} \\
\hline Better off & 70 & 52 & 26 & 52 \\
\hline Worse off & 15 & 28 & 50 & 29 \\
\hline No difference & 13 & 14 & 20 & 15 \\
\hline Don't know & 2 & 5 & 4 & 4 \\
\hline \multicolumn{5}{|c|}{$\begin{array}{l}\text { c. Most farming is done by } \\
\text { private owners or on private } \\
\text { land? }\end{array}$} \\
\hline Better off & 86 & 75 & 61 & 75 \\
\hline Worse off & 5 & 11 & 19 & 11 \\
\hline No difference & 8 & 12 & 17 & 12 \\
\hline Don't know & 1 & 2 & 2 & 2 \\
\hline
\end{tabular}

Source: Boeva and Shironin (1992). Based on a survey of 2,106 urban Russians.

accelerating, although 1992 data are not yet available. Through January 1992, 8,900 small-scale privatizations had occurred. ${ }^{69}$ Approximately 5,000 joint ventures are now operating. Six hundred commodities exchanges are also operating throughout the country as a major wholesale network. And it is anticipated that 50 percent to 70 percent of industrial

69. Kwon (1992b, p. 13). 
capital will be converted into joint stock companies in the coming months.

\section{The Political Context of Reform}

Throughout Russian history, political liberalization has unleashed considerable initiative and economic development. This was true following the post-Crimean War reforms of Tsar Alexander II, which ended serfdom, fostered local representative institutions (the zemstvo, founded in 1864), and established an independent judiciary in the crucial legal reforms of $1864 .^{70}$

This was also true in the post-1905 reforms of Prime Minister Sergei Stolypin, which encouraged capitalistic enterprise, foreign investment, and private land ownership among the peasants. ${ }^{71}$ It was once again true in the New Economic Policies of the 1920s, following the Russian Revolution. In no case was the problem a lack of social or economic response to the new freedoms. Rather, in each case, the problem was a political reversal of the reforms. Alexander II was murdered by terrorists in 1881, ushering in a period of repression under Tsar Alexander III. Stolypin was progressively undercut by the conservative Third Duma and by Tsar Nicholas II, who feared a weakening of autocratic powers. Stolypin was assassinated, probably by state security forces, as his powers were ebbing in 1911. Even then, the progress of land reform continued until the outbreak of World War I. The New Economic Policies were killed by Stalin, who instituted the murderous collectivization policies in the first five-year plan in 1928.

Stolypin was no doubt correct in 1910 that Russia would be "unrecognizable" if it were given ten years of peace, ${ }^{72}$ and, by implication, contin-

70. Solzhenitsyn (1991) speaks sensitively about building local democratic institutions on the basis of the zemstvo tradition.

71. Schapiro (1986, p. 97) describes the success of the land reforms. "By 1916, the last years of the old regime, nearly two and a half million households, or around twenty-four per cent of the total number of households in forty provinces in European Russia, had obtained individual proprietorship, and there were nearly three quarters of a million applications pending. With the aid of the Land Bank, nearly ten million hectares were purchased by the peasants from the landed gentry between 1906 and 1915. Resettlement in Siberia, which was part of the Stolypin land reform, was also successful, and resulted in the creation in new areas of a prosperous and independent-minded peasantry."

72. Cited in Schapiro (1986, p.97). 
ued reforms. ${ }^{73}$ The process was stopped by internal conservative resistance, and perhaps more importantly by the external disaster of World War I. The question today is whether the reforms will similarly be stopped by internal political resistance or external shocks. In many respects, the social and cultural context for reform is better now than during these earlier episodes. Where Stolypin faced a largely illiterate population consisting overwhelmingly of peasants, today's reformers face an urbanized and highly literate population, with modern communications and media to give voice to their concerns. ${ }^{74}$ Nonetheless, Stolypin's political demise serves to remind us of several of the most important political risks now facing the country.

First, Stolypin faced a conservative Duma (parliament), which was heavily weighted toward the land-owning gentry. Stolypin's reforms were not slowed by general social pressures-quite the contrary-but by narrow factional resistance given undue weight in the unreformed executive and legislative institutions. Today, Gaidar's government faces a similar brake in the legislative bodies of the new state. The supreme legislative body, the Congress of People's Deputies, which meets twice a year, and the smaller standing parliament, the Supreme Soviet, which draws its representatives from the Congress of People's Deputies, were elected in March 1990, for five-year terms. The elections were only partially democratic; the Communist Party still maintained its monopoly of power and organized opposition parties still were not tolerated. A significant proportion of candidates were directly nominated by Communist Party structures, with little effective noncommunist opposition. An independent Russian state did not yet exist.

As is well known, the parliament is now divided among former communist hardliners, representatives of state industry (particularly the MIC) and state agriculture, and radical reformers. The Gaidar government can count reliably upon roughly one-third of the votes, though it is often able to win a majority by capturing a proportion of the industrial lobby, together with the more moderate parts of the ex-communist con-

73. According to Acton (1986, p. 138), "between 1909 and 1913, industrial growth averaged 8 per cent per annum and the rate was accelerating . . . . The banking structure became more sophisticated, and directed increasing sums of domestic capital into industry, while foreign capital continued to flow into Russia."

74. We are grateful to Professor Alfred Rieber of the University of Pennsylvania for stressing these important differences. 
tingent. The Supreme Soviet voted in June, for example, to support the government's radical privatization measures, although state managers still hope to capture the process in the implementation phase. The Congress of People's Deputies is even more conservative than the Supreme Soviet. In its first session after the start of radical economic reforms, it refused to support the government's constitutional initiative in support of private land ownership.

While Stolypin's reforms depended heavily upon the support of Nicholas II, who was protective of his autocratic power, the Russian government reformers are backed by Russia's first freely elected leader, Boris Yeltsin, a genuinely popular politician attuned to Russia's needs for economic and democratic modernization. Yeltsin's support, of course, is of decisive importance at this stage, as the legitimate democratic force that can resist the paralysis inherent in the legislative stalemate. Like the U.S. president, the Russian president is a democratic lightning rod of the society. Yeltsin's continued support for radical reforms will likely depend on his judgment of their social sustainability. In the end, the point that we have stressed-that living standards do not fall sharply because of price liberalization-may well prove decisive. President Yeltsin must judge whether the reform path is socially tolerable and adequately supported.

The special position of the "industrial lobby" merits a further observation. During the final two years of the Gorbachev regime and the first year of the new government, the state enterprise managers from the MIC have been the most vocal and best organized political force on the scene. During 1988-90, this group lobbied for protection of its privileged access to resources and credits and fought successfully against the implementation of radical economic reforms ${ }^{75}$ It is widely believed that direct pressures from the group were successful in getting Gorbachev to back away from the Shatalin 500-Day Plan, which would have transformed the Soviet economy into a market economy within 500 days,

75. One of the most remarkable features of the Gorbachev reforms involved the goal of military conversion. Instead of assigning defense establishments to civilian ministers to manage the conversion, the Gorbachev strategy was exactly the reverse: to assign civilian enterprises to the military-industrial complex (under VPK control). In the quest of weakening the grip of the MIC on the economy, Gorbachev actually increased the scope of the MIC, with the result of further delaying the needed changes! See Cooper (1991, pp. 32-33) and Spechler (1992). 
starting on October 1, 1990. Some MIC state managers were among the key backers of the August putsch that sought to overthrow Gorbachev. A less reactionary group of state managers (exemplified by Arkady Volsky, who managed the industrial sector at the end of the Gorbachev regime) sided with Gorbachev and Yeltsin in August 1991, but have continued to lobby aggressively for a slowing down of reforms, and more recently for a change of government and abandonment of radical reform measures.

The political weight of the MIC seems to depend more on Russia's unrepresentative legislative institutions than on broad-based support in the country. The position of the managers is transparently one of special-interest lobbying (in favor of manager-led privatization, low tax rates on industry, and continued cheap credits), rather than a broadbased appeal to the population. Thus the group has found its key support among hardline deputies in the Congress of People's Deputies and the Supreme Soviet, rather than among the wider population.

Moreover, the state managers hardly speak with a uniform voice. Many managers have by this time already taken an ownership position in one or more private firms spun off from their enterprises, so they often have personal stakes in the continuation of market reforms. Many MIC enterprises played a key role in throwing their support behind Yeltsin during the failed putsch. Nonetheless, the anti-government rhetoric emanating from industrial groups is likely to be very strong in coming months because the managers know that the next few months will be decisive in determining their personal positions in the privatized economy. If they can gain control of the privatization process, they believe that they are likely to win a much bigger part of the pie.

One obvious way forward is through new elections, although here too the situation is confused. President Yeltsin has so far resisted calling for new parliamentary elections, partly because the power to call for new elections is unclear and rests in part or whole with the Supreme Soviet itself. Also, Yeltsin has argued that a new constitution should be adopted first (by referendum) and that the profound economic instability should be ameliorated. These are understandable, if debatable, propositions. They set up the very dangerous possibility, however, that the reforms can still be hijacked by conservatives given vastly greater influence through flawed legislative institutions. 
Some Russians and foreign observers doubt the efficacy of free elections in the Russian context. But as with the evidence about Russia's alleged aversion to the market, the belief that Russians care little about democratic institutions and favor strong authoritarian governments is also very questionable. For example, a recent article by Siberian sociologist Valentine Nemirovsky explained that Siberians overwhelmingly favor individual initiative, a market economy, and democratic institutions. Citing a 1990 opinion survey among 1,200 young Siberian respondents, he reports that 40 percent favored a "multi-party system of the Western type," 32 percent favored "a presidential democracy as in the U.S.A.," 10 percent favored a government "by a strong individual," and 18 percent favored "the existing system." 76

\section{The Case for Further Political Reform}

Even aside from new elections, the existing Russian political institutions continue to pose various kinds of risks to the success, or at least the degree of success, of the economic transformation. At risk of dangerous oversimplification, it may be worthwhile to enumerate the most serious problems.

political DeCENTRALization. One of the reasons for the collapse of the Soviet Union was the inability to manage a vast centralized empire from Moscow. Problems in this regard still remain, on two levels. As we have pointed out, Russia still has not abandoned some of the main economic costs of the former Soviet empire. Russia can ill afford to continue this kind of subsidization policy. Second, Moscow cannot realistically hope to govern a highly centralized Russian state, even stripped of the burdens of the other republics. The tax base of the federal government is shrinking rapidly as increasingly powerful regions within the Russian federation demand further control over their resources. The Federation Treaty of April 1992 established the growing autonomy of the regions, but it has not yet resulted in a workable federal system. This will become increasingly urgent in the next couple of years as fiscal pressures intensify. In Eastern Europe, the first step toward decentralization

76. Reported by Nemirovsky (1992, p. 4), concerning the results of a 1990 public opinion survey carried out by the Social Investigation Center of Krasnoyarsk University. 
was elections at the municipal, regional, or provincial level. Such elections should be a high priority on the Russian political reform agenda.

Central bank IndePendence. The Central Bank of Russia currently reports to the Russian parliament. Specifically, the chairman of the CBR is appointed by parliament and CBR policies are subject to approval by the parliament. At the same time, in practice, the CBR is subject to strong pressures from the Russian government. Industry, agriculture, and the energy sectors have each managed to convince the government to pressure the CBR into granting credits.

What is clearly needed is a set of legal arrangements that will free the CBR from the parliament and the government, alike. History shows very clearly that the legal arrangements surrounding a central bank play a critical role in determining central bank policies. The independence of the German Bundesbank from direct political interference, for example, has been a central reason why the deutsche mark has consistently been a stable currency. CBR independence should provide for a CBR chairman and board of directors, appointed for several years and free from the threat of early dismissal; a CBR charter establishing the statutory requirement that the bank pursue the aims of price and exchange rate stability; no governmental or parliamentary approval of monetary policy; a prohibition on subsidized credits; and an end to automatic crediting of the state budget.

We would also support consideration of a further step-a strict currency board-as an institutional device to restrict the issue of domestic credit. With a currency board, the central bank would refrain from all domestic credit expansion; changes in high-powered money would result solely from purchases and sales of foreign exchange at a fixed exchange rate. Typically, the central bank sets the initial exchange rate and reserve level so as to guarantee 100 percent backing of the domestic base money. In Russia, full monetary backing should include all currency, bank reserves, and household deposits at the Russian national savings bank, the Sberagatalny Bank (which, in effect, are claims on the central bank). According to the government of Russia, as of September 1992, this was about $\$ 8$ billion at the market exchange rate. (An even higher starting level of reserves would be advisable in order to support a post-stabilization buildup of money without Russia having to run large balance of payments surpluses.) The gross reserves of the central bank, 
however, are at most $\$ 1$ billion to $\$ 2$ billion, with heavy short-term foreign liabilities that in fact leave Russia, in effect, with negative reserves. Thus the construction of a currency board would require large-scale financial assistance from the West.

PRESIDENTIAL-PARLIAMENTARY SYSTEM. Further progress in achieving political stability will require a new constitution, delimiting the powers of the executive and legislative branches and stating the provisions for future elections. We believe that Russia would be best served by a mixed presidential-parliamentary system in the French mold, also known as a semipresidential system. ${ }^{77}$ In such a system, the directly elected president nominates the prime minister, who must be confirmed by parliament. The president and the prime minister share powers, with the prime minister typically having responsibility for the day-to-day management of the government. The president provides an anchor of stability, as well as insurance against political paralysis, while the parliament and prime minister help to prevent the president from sliding into personalism or despotism. ${ }^{78}$ Russia already seems to be evolving into such a system, but it should now be enshrined in the new constitution.

RULE OF LAW. In addition to constitutional reform to define presidential and parliamentary powers, and new elections for parliament and local governments, Russia must make special efforts to establish an independent judiciary and an executive subject to the rule of law. The Russian autocratic tradition was the antithesis of the rule of law: Tsarist pre-

77. For essays on the comparative merits of the presidential, parliamentary, and mixed-presidential systems, see Lijphart (1992).

78. Jean Blondel's description seems particularly apt for Russia. Blondel (1992, p. 172) argues that "neither parliamentarism nor constitutional presidentialism can be expected to bring about a solution to the problems of a country in which efforts are made to set up a pluralist system, but where the party configuration is weak or insufficiently streamlined. A dual leadership system, on the other hand, may be able to provide a combination of authority and flexibility which can create the necessary conditions for a more stable liberal regime. In a parliamentary system, the president needs the support of the majority of the chamber to keep his government in office; this may be difficult to achieve if the party system is inchoate. But, as the president is elected for a substantial period by universal suffrage, he has authority and can be expected to rally at least some of the political waverers to himself and his government. The party system may then become better organized. The system is not foolproof, but it gives the executive a breathing-space as well as some means of exercising pressure on the chamber, for instance through dissolution and a share in the government." 
rogatives were virtually without constraint. A telling example involves corporate economic activity: until the end of the Tsarist regime, there was no practice of automatically registering Russian corporations, in contrast to the liberal practice in Western Europe..$^{79}$ Later, of course, the Tsarist prerogatives were exercised by the Communist Party. Even today, the patrimonial tradition, in which the political leader assumes personal responsibility for the state, is partly carried over into the system of presidential decrees, although these decrees may now be overridden by the Supreme Soviet.

\section{The Role of the West ${ }^{80}$}

Russian reforms will evolve in part in reaction to events in the West. Just as Stolypin's reforms were cheated out of the ten years of peace that their creator had called for, and just as Stalin's plan was spurred by the disarray of the West during the Great Depression (and by the rise of Hitler), so now the success of Russia's reforms will probably depend greatly on the political and economic stability of the leading Western nations. If the "Western model" of democratic capitalism continues to deliver the goods, it is hard to believe that Russians will turn back from their current path of reforms, even if they stumble along the road. On the other hand, if the West were to enter its own deep economic crisis, it is hard to imagine Russia's reforms succeeding at this juncture, even with the most talented domestic leadership.

On a more positive note, Western financial assistance can probably play an important role in raising the chances for successful transformation. This is now generally acknowledged, after a debate on this point

79. See the fascinating study by Owen (1991). In an overview of the Tsarist regime, Owen (p. xiii) states, "From its inception until its collapse in World War I, the Tsarist autocracy viewed itself as standing above society, subject to no restraints by countervailing social or political institutions. It claimed the right to implement major social and cultural transformations from above, even after it surrendered some of its prerogatives to elected and semi-elected representative bodies in 1906. Despite the economic irrationalities engendered by this attitude of autocratic intransigence, the regime refused to reform the law in response to changing economic conditions in the twelve decades from the accession of Paul I to the fall of Nicholas II."

80. This section draws upon Sachs (1992). 
early in the year. On April 1, the G-7 countries unveiled a $\$ 24$ billion aid program for 1992. The G-7 governments put the IMF in the lead in coordinating the Western assistance. The IMF was given two main tasks in Russia: to provide technical assistance; and to help mobilize international financial assistance, conditional on the implementation of reform measures. Unfortunately, it has done poorly on each task, and has thereby contributed to the current parlous state of the reforms.

\section{The Role of the IMF}

Even aside from the political pressures for cheap credit, we have stressed that the monetary problems in Russia are perhaps the most complex in world history. The problems in moving from a single Soviet currency to several currencies for newly independent states are enormously challenging. The issues in improving the payments system, and in addressing the problem of interenterprise arrears, are urgent. These problems merit an extraordinary effort of international technical assistance, with teams of highly qualified monetary economists, commercial bankers, investment bankers, accountants, and lawyers. The IMF should have mobilized this effort, but so far has not. When it has intervened on the issue of the ruble area, it has weighed in against a rapid introduction of new currencies in the other republics, thereby condemning Russia to absorb unnecessary inflationary pressures from its neighbors.

Dozens of high-quality law firms, investment banks, and accounting firms have well-staffed permanent offices in Russia. By contrast, the IMF does not have a single monetary specialist permanently on the ground in Russia! Incredibly, the core IMF team consists of only seven people, based in Washington, who visit Russia periodically for a couple of weeks. This effort is augmented by other short, fly-in missions of technical assistance. Even though the personnel are often of high quality, the contacts are too superficial to produce the desired results.

The IMF has failed as well in mobilizing the $\$ 24$ billion aid package in a timely and effective form. For 1992, it appears that the IMF will provide only $\$ 1$ billion of its own funds. Moreover, Russia will not even draw upon that money in 1992 because the IMF has insisted that Russia hold the funds in reserves, rather than use them to finance imports. It 
now seems that most of the financial package will not arrive this year, and what has come is overwhelmingly short-term trade credits (of maturities of one to two years, at market interest rates), rather than long-term balance of payments support, or budgetary support that could have obviated the need for inflationary finance.

A simple example will illustrate the problem with this approach. Suppose that Russia must purchase $\$ 100$ million of medicine on world markets and that the budget lacks the tax revenues to make the purchase. With an international loan, the transaction is straightforward: medicine is imported; the loan must be repaid in the future; and no monetary consequence ensues. Without a loan, however, the government must borrow rubles from the $\mathrm{CBR}$ and use the rubles to purchase dollars on the foreign exchange market. The money supply jumps, the ruble depreciates, and prices soar. The full \$24 billion package, used appropriately, would have eliminated the need for most or all the inflationary ruble credits this year and would also have prevented the inflationary depreciation of the exchange rate.

A constructive role for the IMF is still salvageable, especially because the government's reforms in the nonmonetary sphere, particularly in privatization, are going ahead with vigor and intelligence. But success in the monetary sphere will require urgent changes in the IMF approach. The IMF should remain firm in insisting on tight monetary conditions. The point is not to ease conditions, but to help prepare the framework in which the conditions can be met.

First, the IMF should commit to a speed-up of aid, conditional on a reversal of the recent rhetoric and substance of the central bank's monetary policy. Second, the IMF should immediately mobilize several hundred million dollars from the G-7 to support intensive technical assistance, first and foremost in the monetary and banking sectors. The vast majority of personnel will have to come from outside the IMF, but can work along with IMF staff. Third, the IMF should bring to Moscow its most experienced personnel, to remain there all year.

\section{The Role of World Bank and the EBRD}

The World Bank should help to mobilize funds for significant restructuring of key sectors of the economy, including military conversion, financial services, and communications and transport. These World 
Bank sectoral loans should involve a mix of policy conditionality; infrastructure investment (needed to support private economic activity in the sector); and direct financing (equity and debt) for private-sector projects. The World Bank funds should be combined with cofinancing from the export credit agencies and private investors. To support privatization in these sectors, the World Bank should maintain a standard that loans to individual Russian enterprises should be conditional on those enterprises either being private or being corporatized and on the way to being privatized.

At the same time, the EBRD should focus its energies on supporting the rapid development of the private sector. So far, the EBRD has spent excessive efforts on carrying out individual business deals that could just as well have been carried out by private investment banks. The EBRD should instead be working on support for systemic change. One promising model is the U.S. enterprise funds that have been established for Czechoslovakia, Hungary, and Poland. These funds, capitalized by a budgetary appropriation and managed by private U.S. firms, spur private-sector activity in the three Central European countries by making large numbers of small-scale loans and taking direct equity positions in local, private start-up firms. In addition, the enterprise funds work with relevant governmental structures to help develop an adequate legal environment for the growth of the private sector. The EBRD could establish similar operations in Russia and the other states of the former Soviet Union.

\section{Financial Assistance in the Medium Term}

The nature of the financial aid should evolve over time, as the reform program itself is evolving. In the first year of the reform, most attention is necessarily being devoted to macroeconomic stabilization and trade liberalization. In this phase, the aid should be directed mainly to general balance of payments support (financing of imports) and to currency convertibility, through a stabilization fund and a buildup of central bank reserves. In later years, as reform efforts shift to privatization and structural adjustment, the aid should be directed increasingly toward specific investment projects and support for the emerging private sector.

It should be well understood that the official assistance will be insufficient, by itself, to play a major role in "rebuilding" the Russian econ- 
omy. The primary resources for rebuilding will be indigenous savings, over the course of decades. But even within the limited domain of foreign capital, it will be private inflows, rather than official assistance, that will have the greater role in the long term. Private capital, mainly in the form of foreign direct investment, will bring with it not only resources, but critically needed technology, management skills, links to Western markets, and so forth. Having noted this, however, we must be realistic about the timetable for significant foreign capital flows, which will only come about on a large scale after a few years of successful reform (with the exception of some projects in particular sectors, mainly oil and gas).

\section{An Institutional Framework for the Medium Term:}

The Role of the G-7

In the first year of reform, Russia's links with the IMF and the World Bank will provide the basic framework for conditional financial assistance. As the reform issues move beyond immediate stabilization and liberalization, however, those institutions alone will be unable to manage the range of issues that will arise between Russia and the West in the course of reforms. Almost every aspect of structural adjustmentwhether in energy, military conversion, international trade, financial sector reform, or environmental policies-involves a complex linkage of private-sector initiatives, public policy changes, and infrastructure investment that will require the active involvement of Western governments, together with the Russian government. A broader framework of cooperation will be needed during the process of reintegrating Russia in the world system. The G-7 is the natural locus of that cooperation.

An analogy is helpful here. In the case of the Central European countries, the European Community is the natural counterpart in the medium term for problems of structural reform. The Central European countries want to join the EC, and so are designing their reform policies with the goal of eventual membership very much in mind. The Association Agreements reached between the EC and Czechoslovakia, Hungary, and Poland in 1991 provide the broad framework through which the process of harmonization and eventual EC membership will take place.

Russia, like Central Europe, aims to become a normal member of the world economic community. But in the case of Russia, its size and potential economic strength make it a natural candidate to become a lead- 
ing member of the G-7 (thereby making it the G-8), rather than a member of the EC. Just as the Association Agreements with the EC will be crucial guideposts for Central Europe in the next few years, a structured relationship between Russia and the G-7 could provide an overall framework for cooperation, leading eventually to Russia's normal participation as a member of the eighth member of the group.

The G-7 should invite Russia to attend G-7 ministerial meetings on a fairly regular basis, in order to maintain a high-level political and economic dialogue on the progress of the Russian reforms and Western support for them. Moreover, it should become standard for the Russian president to attend part of each summit meeting. As the chairmanship of the G-7 rotates each year (to the country hosting that year's summit), the G-7 chairman for the year should be assigned the overall responsibility for coordinating the G-7's efforts vis-à-vis Russia, including oversight over the IMF, World Bank, and EBRD operations in Russia. 


\section{Comments and Discussion}

Vladimir Mau: The draft of this paper was entitled "The Struggle with Russian Economic Reform." I was told that this sophisticated title was a mistake. Nonetheless, it is a very characteristic mistake. It reminds me of an old joke told in Russia during the Cold War. Commentators on Armenian Radio are asked whether World War III is possible. They answer, the war itself is impossible. But what really is possible is a terrible struggle for peace, which will destroy everything.

In these remarks, I would like to address the social and political context of the so-called struggle for economic reform. I want to concentrate on the last part of this report: the social and political context of Russia's transformation toward a market economy. Broadly speaking, I agree with most of the ideas included in this paper. However, I would like to add a few points.

A real shift is occurring in the mind-set of the common people in Russia. In the public mind, self-reliance is replacing paternalism and statism. At the same time, the public is increasingly disregarding events surrounding the political struggle-or any political events. This shift is evident in opinion polls conducted in 1991. Lack of confidence in all political parties and institutions has increased markedly since the beginning of this year. The issues of real concern, especially in the Russian provinces, are immediate issues of daily life, particularly how good this year's harvest of potatoes and other crops will be on private plots of land.

Our analysis and experience confirm this turning inward and David Lipton and Jeffrey Sachs acknowledge it in their paper. I agree with them that this shift in the public mood may play an important and positive role during the dramatic and painful changes that lie ahead. 
Let me mention an interesting and typical example of the public's political neutrality. In the first half of this year, I analyzed various political manifestations and demonstrations in Moscow, paying special attention to the social structure of the participants. It was identical, either at communist-oriented meetings or at democratic ones. Pensioners dominated both sides, making up about 40 percent of participants. White collar workers followed, at about 25 to 30 percent. Then came students. Less than 10 percent of the participants were workers. Yet in Russia, during this period of sharp tensions, workers are considered to be the decisive force.

I do not think that we should exaggerate this finding and portray it as representative of the bulk of the population. Various polls in Russia now display the typical contradictions in people's thinking about the rationale and purposes of market-oriented reform. For instance, according to a poll conducted in May-June, 1992 by the Institute of Sociology, about half the Russian population views the steps the government is taking toward a free market economy as correct. Seventy-one percent agree that the government should give people full economic freedom. Sixty-four percent believe that private property rights for land should be permitted. Nearly half-48 percent-agree that the growth of free entrepreneurship and the influx of foreign capital would be desirable. At the same time, 70 percent of the people support government price controls. An even higher percentage-88 percent-say that the government should at least fix retail price levels. Sixty-seven percent of respondents believe that the best way to privatize firms is to turn enterprises over to their workers and employees. Seventy-nine percent say that the government is obliged to maintain full employment. ${ }^{1}$

Moreover, polls in both Moscow and the provinces reveal the public's growing agreement with the ideas of the leaders of the August 19, 1991 coup to overthrow Soviet President Mikhail Gorbachev. As many as 40 percent of those polled now support the slogans of the coup. Respondents do not sympathize with the plotters; they are not sorry that the coup failed. But a good portion of the population supports the slogans because they represent stability, definite prospects, and the probability of moderate change.

An important consequence follows from my observation about the

1. Institute of Sociology (1992, pp. 5, 7, 12-13). 
political neutrality of the people. The real prospects of economic and political transformation in Russia depend on the balance of forces in the top stratum of society. This elite includes the president and his administration, the executive branch, influential factions in the parliament, and leaders at the headquarters of the main pressure groups. The majority of the people will not participate in the political process actively and directly (except in Moscow and several huge industrial centers). Most people will not struggle for or against definite political forces. They will support the force that promises and convinces them that it will be able to ensure a modicum of order and stability.

What is happening in this top stratum of society? The real situation there, and especially in the executive branch, has changed since summer. The "government of the team" created in November has been replaced by the "coalition government." The former had no real social basis and could not obtain widespread support because the first steps of radical economic reforms (in the form of price liberalization in January 1992) adversely affected all strata in the society. In a democratic state, such a situation cannot be maintained for long. The team of reformers had to seek political allies in and out of parliament. They found allies among the "industrialists": managers of state enterprises. This new alliance helped to change the image of the government, which now has more leeway and clout to make economic policy.

The most important positive result of the formation of the coalition government is the split in the ranks of those opposed to radical economic transformation. It is natural that this phase of Russian reform should be accompanied by the growth of opposition and the polarization of social forces. But this is not the main threat. What is much more dangerous is the amalgamation of influential forces and pressure groups that have fundamentally different purposes and long-term interests-groups that would never support one another, except as an extreme and last resort. Thus prudent and delicate political actions to prevent total opposition to the reforms are exceptionally important.

An anti-government alliance emerged in the middle of the spring when many enterprises and firms were frightened by the government's intention to liberalize fuel prices. Private and state enterprises, industrialists and farmers, members of the military and industrial complex, and producers of consumer goods-all types of economic agents united in opposition. Moreover, the opposition appeared to be a united front of 
almost all of Russia's producers, especially managers of the state enterprises.

The formation of the coalition government undermined the unity of that opposition, which nonetheless grew rapidly into a powerful political bloc. An attempt on August 13-14, 1992 by the rigid opposition in the parliament to organize anti-reform action and change the government failed; the majority of enterprises managers did not support that action. That was the coalition government's political success.

But the price of this success has been high. As I write in the fall of 1992, when the inflation rate has been increasing and ruble exchange rate has collapsed, that price seems to be extremely high. Coalitions and compromises are inseparable. The results of these compromises may be dangerous: inflation and unemployment.

Economists in the West usually consider inflation to be the worst turn of economic events, especially when compared to unemployment. Most foreign consultants in Russia have insisted that growing unemployment is less dangerous for political stability and the prospects for market reforms than growing inflation. But the situation in Russia is not so clear. By 1992, people and enterprises have already become accustomed to living with rising prices. This adjustment comes from long discussion in our society about the price system well before 1992, as well as personal experience since the reforms were launched on January 2, 1992. Certainly, inflation is a serious problem, but Russians now know how to live and to work with it. Polls reveal that the share of those who are dissatisfied has been declining, up to August 1992. The same is true about the share of people who are dissatisfied with price liberalization. (For instance, in Moscow that share fell from 36 percent in June to 30 percent in July.) ${ }^{2}$

However, all strata of Russian society now view unemployment as the worst outcome. Yet the growth of unemployment is inevitable if market transformation is to continue. I think that the bulk of the population now realizes this. Moreover, the growth of unemployment would be a sign of real economic transformation-of the beginning of structural changes in Russia's national economy. (The employment statistics up to September demonstrate only nominal growth of unemployment, with no real shifts in the labor market: 202,900 workers were officially unemployed in July; 107,800 received unemployment compensation; about

2. Mnenie Service (1992). 
800,000 asked for government help in finding a job; and enterprises' estimates of new job openings has stood at about 400,000 workers. ${ }^{3}$ The figure on job openings has been decreasing this year, but the decline has not been sharp. These figures are small in comparison with the Russia's population, but they are increasing, and their growth is expected to accelerate in November.)

On the one hand, unemployment poses a psychological problem. People need enough time to get accustomed to new realities (as is occurring with regard to price liberalization). Thus the speed of transformation is itself a problem. On the other hand, unemployment is a political problem because on this issue, the interests of different pressure groups interconnect. Some industrial managers seek new prospects in their activities as entrepreneurs. Some understand that the growth of unemployment will be triggered by the bankruptcy of firms exposed to market forces. This will be an issue of dramatic tension in the near future. And on this point, reformers in the government had to concede to the industrialists. This is why since mid-summer, credit has expanded dangerously, pushing up inflation. We should not underestimate the social danger of this problem or be lulled by the formal analysis of statistical data. For instance, the Lipton-Sachs paper argues that "if the share of workers in distribution and finance were to rise from 8 percent of the labor force to just 15 percent of the labor force (which would still be far below the share in typical market economies), about 9.6 million new jobs would be created in trade and distribution. That would be enough to compensate for an employment decline of 44 percent in heavy industry, which itself is likely to be an overestimate of the actual decline."

I cannot agree with such calculations. The numerical assessment of employment prospects and unemployment is probably correct. But this is not simply a question of retraining and reeducating workers, which is complicated enough. A good part of the workers from heavy industry will never be involved in commerce or financial sector. The mentality of the people and their basic skills can not be changed by education. This is a generational problem.

So Russians now face slowly growing unemployment and increasing inflation. Moreover, the inflation rate is increasing in the fall of the year. This is extremely dangerous because it dampens farmers' intentions to

3. State Committee of the Russian Federation on Statistics (July 1992) and "The Socio-economic Status of the Russian Federation in the First Half of 1992," Ekonomicheskaya Gazeta, No. 30, July 1992, p. 5. 
sell their crops, either to the public or to state procurer organizations. The later they sell their crops, the more revenue they will earn. This behavior will present specific difficulties to the government, which must ensure industrial centers that bread will be available and could provoke it to use so-called "extraordinary measures" or (to put it simply) to confiscate most of the crop.

Historical examples are popular now and they are used often in this paper. I would like to offer the reminder that the most dramatic shifts in Russian history in the twentieth century were brought about by a parallel situation in the villages.

Another issue of political struggle and compromise is privatization. This process is occurring with vouchers (or privatization coupons). This approach has its own benefits, but vouchers present some dangerous social consequences. Vouchers can help accelerate the process of privatization and concentrate assets rapidly in the hands of real entrepreneurs. Moreover, vouchers might have an important psychological result if they increasingly shift people's thinking to issues of their market behavior and to the problems of the enterprises where they work.

At the sametime, vouchers can increase the discontent of people whodo not fare well in the process. (Nobody can now recommend vouchers as the best way to invest because no real market criteria exist.) I am not sure that the state firms that have been transformed intojoint stock companies will be glad to obtain vouchers. I think they would prefer real money.

Russia has no investment institutions, trust companies, or other organizations that could help people dispose of vouchers. Moreover, there is no effective system to insure the deposits of the common people-the potential small shareholders. In the end, the redistribution of vouchers will accelerate inflation by injecting more money into the market of consumer goods. (That is, the funds accumulated for investment by potential voucher-buyers will be transformed into earnings of the humble man who sells his vouchers.)

These problems can be solved and even turned into benefits. For example, if the excess of consumer demand is channeled to the market of durables-to the advanced branches of industry, which now suffer from a lack of demand for their products-this important sector of the Russian economy could be stimulated without accelerating inflation. ${ }^{4}$

4. This point was made by Irina Starodubrovskaya in an oral presentation in 1992 to the government of Russia's Working Center for Economic Resources entitled "Microeconomic Issues of the Stabilization Program." 
The balance of forces in Russian society and the prospects of economic and political transformation can certainly be compared with the reforms underway in Eastern Europe. I agree that comparisons with Poland, for instance, are important for better understanding the economic processes in Russia. But to what extent do the features of various countries differ? The authors acknowledge the peculiarities of economies in transition. Nonetheless, they stress that the differences are not extremely meaningful in analyzing the current situation.

However, I must point out that political and social characteristics differ radically in the various countries. Russia has important features that lead to very specific social conditions surrounding the reforms. Notably, while the Eastern European states (including the Baltic states) are now moving out of a system that was imposed upon them by external force, Russia must overcome a regime that was created from within. That is why no consensus exists in Russian society about the key issues of further development of Russian society. This lack of consensus has led to dramatic and sharp social struggle, which is evident in the parliament and in the streets. To put it more correctly, this process of transformation should be considered a revolution: one characterized not only by the struggle of different political parties, but by the real struggle among social forces around issues of historical choice.

Finally, the Lipton-Sachs paper, and especially its section on politics, contains an interesting historical dimension. The authors stress that throughout Russian history, political liberalization has unleashed considerable initiative and economic development. They cite the examples of the reforms of Tsar Alexander II in the 1860s, the course of Prime Minister Stolypin from 1906 to 1911, and the New Economic Policy of Lenin in the 1920s. All these attempts to liberalize economic life in Russia resulted in periods of cruel reaction. This topic needs a separate analysis. I would like to emphasize only one point: the three attempts mentioned above were launched in a very contentious political environment.

All were characterized by a lack of political democracy-a factor that was one important reason for the depth of the reforms. Alexander II ended serfdom and created the zemstvo. However, these steps prompted extremely reactionary national policy, which destroyed key powers of the Russian empire, where political loyalty to the regime was much more important than nationality for one's civil status. I do not like to support the political position of the Russian Duma, but Stolypin was 
not a prominent democrat. And the economic liberalization of the $1920 \mathrm{~s}$ occurred under a deteriorating and increasingly repressive political climate in the Soviet Union.

Now the Russian government is trying to bring about radical changes in the political and economic system. The most important feature of this period is an attempt to combine political and economic liberalization. This combination presents complicated social conditions for the transformation, as well as new problems for the reforms. Nonetheless, from a strategic standpoint, this political climate may be more favorable to lasting success. At the same time, the processes of liberalization and democratization in the society will survive only if they are completed by a strong executive power that exerts control over the entire Russian Federation. I believe that this power is not only desirable, but inevitable. If democratic forces are unable to ensure this power based on the democratic procedure, it will be established by a Russian reaction, with all the tragic consequences for the social, political, economic, and cultural prospects for the state-and even for the rest of the world.

Edmund S. Phelps: I yield to no one when it comes to admiration for Jeffrey Sachs and his team in Russia. The talent and the range of competence are extraordinary in a profession suffering from long overuse of mathematics as a sort of steroid.

That said, I must add that there seems to be more cause for worry about the Russian reform plans than David Lipton's and Jeffrey Sach's report reflects.

The worry is that the benefit of the reform program in its current state could fall far below what is possible-and what one hopes is politically feasible-because the insiders will have enough power to preserve some of their advantages.

Recall the story of the creature artificially constructed by Dr. Frankenstein. A brute of a man, he was strong in a number of resources and full of drive; yet he suffered from a flaw in design. His creator did not include an appropriate kind of brain, so he lacked the suitable control mechanisms.

The parallel danger in Russia is that the government, in its design of a market economy, is drawing up a defective system that lacks corporate governance mechanisms for enterprise control. (It also lacks mecha- 
nisms for monetary and fiscal control. I will not be able to discuss those, but the report examines them at some length.)

The risk is that this mutant system will be unable to perform with the efficiency and the dynamism of a normal capitalist market system. The Lipton/Sachs report would have benefited from an evaluation of the extent to which the new Russian plans are a solution to this problem of enterprise control.

On this subject, Jeffrey Sachs, I think, has for some time given the impression that well-functioning markets plus competition of private firms-together with an end to soft budgets through fiscal policy and hyperinflationary monetary policy-would be sufficient. A number of economists agree with that view.

But in the view of many of us, to achieve the potential of a capitalist market economy, instituting a price system (by decentralizing resource allocations and deregulating enterprises) and instituting private enterprise (by legalizing private ownership of shares and enacting mass privatization) are necessary, but far from sufficient, steps.

The step that is missing in the privatization plan at present-the very brain of the creature-is the creation of appropriate mechanisms of enterprise control by owners and creditors. Control here means that outsiders, the owners, or, in some contingencies, the creditors, can set the direction of the manager, monitor the management, and change the manager: all to ensure that the enterprise is aimed and equipped to maximize expected profits.

Without mechanisms for owner control, each enterprise will tend to be misdirected by its manager. The allocation of investible funds across industries will be driven more by considerations of control than the technically possible rates of return. Moreover, the cost of equity finance will tend to be inflated, especially insofar as funds can go abroad.

Somewhat similar safeguards are also needed for potential creditors, giving them the right to intervene in the event of default. Otherwise, the cost of debt finance will be forced higher and the availability of credit will be curtailed. Where credit goes will be dictated by collateral rather than the worthiness of investments. Moreover, there will be no creditors in the driver's seat to overthrow the management in extreme cases, thus leaving it up to the shareholders, who may have failed to be effective before.

For concrete examples of such control mechanisms and governance 
mechanisms, I would mention, in particular, the two governance mechanisms that receive good marks in a paper by Roman Frydman, Andrzej Rapaczynski, Andrei Shleifer, and myself, written for the European Bank for Reconstruction and Development. ${ }^{1}$

The first is an old Frydman/Rapaczynski idea: a group of financial intermediaries set up to hold large blocks of shares in the large enterprises, as part of the process of mass privatization. These intermediaries would be induced to exercise active ownership functions, such as I mentioned before.

The second mechanism is the institution of large banks in the German or Japanese style. These would supply credit under the usual bankruptcy protections and be encouraged to take an active role when things go wrong.

These proposals seem straightforward. What is the difficulty? If corporate governance mechanisms are widely seen to be beneficial and, indeed, crucial, why should we not expect the government to institute some of these mechanisms in the course of the privatization program or soon thereafter?

I suspect that the difficulties lie with two vested interest groups of insiders in the not-yet-privatized socialist enterprises: the enterprise managers and the enterprise employees. Both groups have been trying to pressure the government to privatize through a sort of buyout of the insiders. The government would offer them a large chunk of the shares in their enterprises at favorable terms or give them the shares outright.

As far as I can see, the insiders have been succeeding to a considerable degree. Two variants of the privatization scheme are underway. Under Variant 1, shares are given away to insiders, but not in large enough amounts to control an enterprise. In Variant 2, which the managers can opt for, insiders at an enterprise can buy up to 51 percent of the shares at very favorable terms. In this scenario, any outside investor, contemplating an attempt to gain control, probably would view the task of unseating the manager as a pretty tall order.

The Russian plan does not, as I understand it, build into the privatization process mechanisms for outsider control. Provisions are not being made for financial intermediaries to hold large blocks of shares, expressly with the aim of exercising at least a measure of outsider control

1. Phelps and others (1992). 
over the enterprise. Moreover, some hurdles have been put up to hinder outsider control.

As I understand it, the government is not caving in entirely. It is trying to saddle Variant 2 with onerous requirements to induce the managers, instead, to opt for Variant 1 , in which shares are of smaller amounts and nonvoting. That seems to be a good deal better. How much better, it is hard to say.

So, a struggle seems to be occurring as to what kinds of enterprises are going to be created in Russia. This could be the real battleground where the success of the market economy now being created is finally determined.

Some of the possible positions on this question are already clear. It can be argued that the enterprise control mechanisms can always be created later when the government is stronger or has more time. Or it could be argued that suitable mechanisms can be left to evolve; with good luck, the right sort will evolve the first time around and be recognized as right.

Either case contains risks. A privatized system, left to operate before effective mechanisms of outsider control of the enterprises have been instituted and left to the piloting of self-interested managers (and employees, in some cases), will not be enterprising enough to undertake the desirable restructuring on a wide scale. Thus it will prove too weak to stand independently of the state. Soft budgets could result, and the whole process could come undone. What would happen next is unclear.

If control mechanisms do arrive, they may arrive too late to halt the downward spiral of real wages and capital that has been occurring since the insiders gained control of the enterprises toward the end of the 1980s.

This is not a council of perfection. Like Lipton and Sachs, I believe that it is better to privatize in advance of good governance mechanisms than to wait for everything to be in place. But in my view, it is terribly risky to fail to set up, early on, some control mechanisms to restrain and redirect the managers. If these mechanisms do not arise or they are not built in, I am afraid Frankenstein's monster may prove to be an applicable cautionary tale. 


\section{General Discussion}

Responding to Edmund Phelps' comment, Jeffrey Sachs said that he was not only sympathetic to the idea that corporate governance issues are important, but that he and David Lipton had introduced the debate about corporate governance in the Eastern European context in 1990 with their proposal for investment funds. Their 1990 Brookings paper on privatization was all about the corporate governance issue $(B P E A$, 2:1990).

The depth and scope of the entrepreneurial spirit sweeping through Russia drew several comments. Richard Cooper questioned the assertion-based on recent polling data-that attitudes toward entrepreneurship are no different in Russia than anywhere else. Although Russia may face no shortage of potential entrepreneurs, Cooper cautioned that it is not yet clear how the Russian people will deal with the distributional consequences of economic changes. As the Russian proverb says, a Russian would rather die of hunger than of envy. Alan Blinder also wondered whether the social fabric of Russia could cope with the strain of rapid change. Julio Rotemberg added that, while the increased entrepreneurial activity in Russia may be welcome, studies of small-scale enterprises in lesser developed countries show how precarious and often marginal these types of businesses are.

Alan Blinder asked how relevant the Chinese example of incrementalist transformation would be to Russia. Jeffrey Sachs noted large differences between Russia and China. In China, three-fourths of the population lives in rural areas, so that rural reforms after 1978 liberalized a huge proportion of the economy. Rapid growth has taken place outside the planned sector of the economy; meanwhile, state-owned planned industries have continued to suffer enormous financial losses. By contrast, Russia is heavily industrialized and urbanized. Almost all economic activity in Soviet Russia was state-controlled. Hence, Sachs argued that the lessons of Chinese gradualism in industrial reform have little relevance for Russia.

Cooper wondered how well the Russian economy could be expected to manage the historic reallocation of resources that was envisioned by reformers. He reported that retraining in at least some sectors seems to be proceeding well: retired and cashiered army officers are being suc- 
cessfully retrained as tax collectors! But he asked whether the surplus labor released from failed enterprises could be absorbed in the cities, and particularly wondered how employees in specialized one-company towns would find alternative employment. David Lipton reasoned that no alternative existed to scaling back some of the heavy industries and that the expanding service sector could absorb the labor released by their decline, as it has done in other economies.

Stanley Fischer questioned the paper's implication that whatever happens after markets are freed represents an improvement on the status quo ante. He asked what path of output decline the authors would consider a deterioration in economic conditions and called for a clearer distinction between the short-term costs and long-term benefits of the transition. Rotemberg also observed that price liberalization in itself is not necessarily a good idea; recent experience in Eastern Europe shows that it invariably results in higher prices, inducing a severe recession. Fischer added that the paper does not adequately address the question of the appropriate speed of reforms. David Lipton noted that rapid reforms in monetary policy were called for because of the risk that continuing high inflation could become hyperinflation, which would cripple real economic activity in a major way.

Fischer took issue with the idea that central bank independence to control the money supply was necessarily a good thing, pointing to the recent expansion in the Russian money supply, which occurred under a central bank that was independent of the government. Rather than trusting in independence per se, he suggested that the proper conduct of monetary policy should be framed as a broader and explicit policy issue. Lipton noted that the Russian central bank, under its acting president, is not independent, but rather acts under the control of Parliament. The recent extension of a large volume of industry credits was a parliamentary decision made on political grounds, not the action of an independent central bank. Greater independence would reduce such political influences over monetary policy.

Fischer also disagreed with the paper's recommendation to establish a currency board for Russia, reasoning that it would be too expensive for a country of Russia's size to hold the necessary quantity of hard currency. Robert Hall suggested encouraging the use of U.S. currency in Russia, with the seigniorage returned to Russia by the Federal Reserve. 
Hall also drew attention to the weakness of a financial system that issued currency to finance its generous granting of credit. He argued that it was more important to create intermediary institutions that extended credit by attracting domestic sources of funds, so as to avoid the current banking system's built-in inflationary bias.

Fischer proposed a two-part strategy for providing aid to Russia. First, the West should provide $\$ 8$ billion to $\$ 10$ billion a year in basic aid, independent of the progress of reforms. Second, additional assistance should be made conditional on Russia's reaching a standby agreement with the IMF, thereby increasing the Fund's role in the conduct of policy. Hall pointed out that the paper makes only a weak case for U.S. aid, portraying it mainly as a way to buy credibility for U.S. advice.

Olivier Blanchard asked how the position of Russia would be improved if subsidies to other republics were ended. Sachs replied that subsidies in the form of credits to business and artificially cheap oil appear to be between 5 and 10 percent of Russian GDP. As to why these high-cost subsidies are maintained in a time of austerity, he said that a strong lobby of Russian producers favors continuing to extend credits to other republics to finance purchases of Russian output.

The situation in the oil industry drew several further comments. William Nordhaus quoted oil industry sources who confirmed that a large decline in production has occurred and who attributed the decline to poor maintenance of equipment. He suggested that the main concern should be the loss of central government control over the oil industry. Previously, oil export taxes contributed $\$ 30$ billion to revenues, but oil tax receipts have now fallen to zero. Fischer questioned the data for the energy sector, which show little decline in energy consumption, but an extreme drop in exports. He argued that oil exports were in fact high, but were unreported and constituted a form of capital flight.

Mancur Olson argued that the paper gave too much emphasis to privatization. In most formerly communist countries, private rights to property are ambiguous and insecure, so "privatization" does not have a clear meaning. He contended, moreover, that many if not most of the large state-owned enterprises do not appear to be viable in an open market economy. They are kept alive by the government because they are powerful insider lobbies. He conjectured that the fastest growth could be obtained by giving first priority to improving property and contract- 
enforcement rights rather than to privatization because this would greatly increase investment by new enterprises and by foreign firms. Sachs responded that the privatization issue was not as clearcut as Olson suggested: not all firms need to be liquidated after privatization, and some valuable opportunities have already been exploited by privatized firms. 


\section{References}

Acton, Edward. 1986. Russia. New York: Longman.

Alexashenko, Sergey. 1992. "The Collapse of the Soviet Fiscal System: What Should be Done?" Unpublished paper. Bank of Finland.

Ammeter-Inquirer. 1992. "Poland: Results of a Survey of Economic and Political Behaviour." Studies in Public Policy No. 201. University of Strathclyde, Glasgow: Centre for the Study of Public Policy.

Aslund, Anders. 1992a. "The Gradual Nature of Economic Change in Russia." Paper prepared for the Conference on the Change in the Economic System in Russia, Stockholm Institute of East European Economics, Stockholm School of Economics (June 15-16).

— 1992b. "The Economic Crisis in Russia: How to Promote the Reform Process." Paper prepared for the Joint Hearing of the European Parliament: Economic and Political Problems of the former Soviet Union, Brussels (September 10-11).

$\rightarrow$ Berg, Andrew, and Jeffrey Sachs. 1992. "Structural Adjustment and International Trade in Eastern Europe: The Case of Poland." Economic Policy 14:117-73.

Biuletyn Statystyczny (Monthly Statistical Bulletin). 1990-92, various issues. Warsaw: Central Statistical Office.

Blondel, Jean. 1992. "Dual Leadership in the Contemporary World." In Parliamentary versus Presidential Government, edited by Arend Lijphart. New York: Oxford University Press.

Boeva, Irina, and Viacheslav Shironin. 1992. "Russians Between State and Market: The Generations Compared." Studies in Public Policy No. 205. University of Strathclyde, Glasgow: Centre for the Study of Public Policy.

Boone, Peter. 1992. "Russia's Balance of Payments." Paper prepared for the Conference on the Change in the Economic System in Russia, Stockholm Institute of East European Economics, Stockholm School of Economics (June 15-16).

Brainerd, Betsy. 1992a. "Current Employment Policy in the Russian Federation." Unpublished memorandum. Harvard University (August 28).

- 1992b. "The Current Labor Market Situation in the Russian Federation." Unpublished memorandum. Harvard University (August 28).

British Broadcasting Corporation. 1992. Summary of World Broadcasts (October 13, part 2, Special Supplement).

Central Intelligence Agency. 1990. Handbook of Economic Statistics. Washington: Government Printing Office.

Cooper, Julian. 1991. The Soviet Defence Industry: Conversion and Reform. London: Pinter Publishers.

Djelic, Bozidar. 1992. "The Mass Privatization Program in Russia: The Role of Vouchers." Unpublished paper, Institute for International Development, Harvard University (September). 
The Economist. 1990. The Economist Book of Vital World Statistics. London: Random House.

Fischer, Stanley. 1992. "Stabilization and Economic Reform in Russia." BPEA,1:1992, 77-111.

Friedman, Milton. 1992. Money Mischief: Episodes in Monetary History. New York: Harcourt Brace Jovanovich.

Hansson, Ardo, and Jeffrey Sachs. 1992. "Estonia's Monetary Independence." Transition. Washington: World Bank (forthcoming).

Institute of Sociology. 1992. "Mirror of Opinions: The Result of a Sociological Poll of the Population of Russia." Moscow: Russian Academy of Sciences.

International Monetary Fund. 1992a. "Russian Federation." Economic Review. Washington.

- 1992b. "The Economy of the Former U.S.S.R. in 1991." Economic Review. Washington.

Joint Study. 1991. A Study of the Soviet Economy, 3 vols., by the International Monetary Fund, the World Bank, the Organisation for Economic Cooperation and Development, and the European Bank for Reconstruction and Development. Paris: Organisation for Economic Cooperation and Development.

Keynes, John Maynard. 1920. The Economic Consequences of the Peace. New York: Harcourt Brace and Howe.

Kornai, Janos. 1992. The Socialist System: The Political Economy of Communism. Princeton, N.J.: Princeton University Press.

Kwon, Goohoon. 1992a. "Productivity, Specialization, and Coordination in the former Soviet Sectors: Evidence and Reasons for Failure." Ph.D. dissertation, Harvard University (March).

1992b. "Survey Paper: 1992 Privatization in the Russian Federation." Paper prepared for the State Committee of the Russian Federation for the Management of State Property (August 18, 1992: draft).

Lijphart, Arend, editor. 1992. Parliamentary versus Presidential Government. New York: Oxford University Press.

Lipton, David, and Jeffrey Sachs. 1990a. "Creating a Market Economy in Eastern Europe: The Case of Poland." BPEA, 1:1990, 75-133.

. 1990b. "Privatization in Eastern Europe: The Case of Poland." BPEA, 2:1990, 293-333.

Mau, Vladimir. 1992. "Bread, Democracy, and the Bolshevik Coup." Business in the Ex-USSR, 19 (January):62-4.

Nemirovsky, Valentine. 1992. In Siberian Manager Magazine, (1):4.

Owen, Thomas C. 1991. The Corporation under Russian Law, 1800-1917: A Study in Tsarist Economic Policy. New York: Cambridge University Press.

Phelps, Edmund S., and others. 1992. "Needed Mechanisms of Corporate Governance and Finance in Eastern Europe." Paper prepared for the Economic Advisory Committee, European Bank for Reconstruction and Development (September 3). 
Pipes, Richard. 1974. Russia under the Old Regime. New York: Charles Scribner's Sons.

"Quarterly Report on Economic Development." Government of Russia. 1992, Quarter 2 (draft).

Radio Free Europe. 1992. Research Report 1:36 (September 11).

Roberts, Bryan. 1992. "The J-Curve is a Gamma-Curve: Initial Welfare Consequences of Price Liberalization in Eastern Europe." Unpublished paper, Massachusetts Institute of Technology (July).

Rosovsky, Henry. 1966. "Japan's Transition to Modern Economic Growth, 1868-1885." In Industrialization in Two Systems: Essays in Honor of Alexander Gerschenkron, edited by Henry Rosovsky. New York: John Wiley \& Sons, Inc.

Sachs, Jeffrey. 1992. "Western Financial Assistance to Support Russia's Reforms." In Making Markets: Economic Transformation in Eastern Europe and the post-Soviet Republics, edited by Shafiqal Islam and Michael Mandlebaum. New York: Council on Foreign Relations (forthcoming).

Sachs, Jeffrey, and David Lipton. 1992. "Remaining Steps to a Market-Based Monetary System in Russia." Paper presented at the Conference on the Change in the Economic System in Russia, Stockholm Institute of East European Economies, Stockholm School of Economics (June 15-16).

Schapiro, Leonard. 1986. Russian Studies. New York: Viking Penguin Inc.

Shiller, Robert J., Maxim Boycko, and Vladimir Korobov. 1992. "Hunting for Homo Sovieticus: Situational versus Attitudinal Factors in Economic Behavior." BPEA, 1:1992, 127-81.

$\rightarrow$ Simes, Dimitri K. 1992. "America and the Post-Soviet Republics." Foreign Affairs 71(3):73-89.

Solzhenitsyn, Aleksandr I. 1991. Rebuilding Russia: Reflections and Tentative Proposals. New York: Farrar, Straus and Giroux.

Spechler, Martin. 1992. "Conversion of Military Industries in the Successor States of the Soviet Union." Working Paper 92-4. Indiana University-Purdue University.

State Committee for the Management of State Property. 1992. The 1992 Privatization Program of the Russian Federation: Description and Explanation. Moscow: Government of Russia (July 23).

Sundararajan, V. March. 1992. "Central Banking Reforms in Formerly Planned Economies." Finance and Development 29(1): 10-13.

World Bank. 1992. "Russian Economic Reform: Crossing the Threshhold of Structural Change." Unpublished paper, Washington (August 5).

Wulf, Herbert. 1992. "Conversion from War to Peace: Conditions for a Peace Dividend." Paper prepared for the Joint Hearing of the European Parliament: Economic and Political Problems of the former Soviet Union, Brussels (September 10-11). 